\title{
The End of Gatekeeping: \\ Underwriters and the Quality of Sovereign Bond Markets, 1815-2007*
}

\author{
Marc Flandreau, Juan H. Flores, Norbert Gaillard, Sebastián Nieto-Parra^
}

Revised, June 2009

\begin{abstract}
We provide a comparison of salient organizational features of primary markets for foreign government debt over the very long run. We focus on output, quality control, information provision, competition, pricing, charging and signaling. We find that the market set up experienced a radical transformation in the recent period and interpret this as resulting from the rise of liability insurance provided by rating agencies. Underwriters have given up their former role as gatekeepers of liquidity and certification agencies to become aggressive competitors in a new speculative grade market.
\end{abstract}

Keywords: certification, primary bond market, sovereign debt crises, banks competition

JEL Classification: F34, G14, G24, N2

\footnotetext{
$*$ This is the revised draft of a paper presented at the NBER International Seminar on Macroeconomics, Cyprus, June 12-13, 2009. The authors are indebted to interviewees from origination departments of investment banks and institutional investors for field research conducted in New York (Winter-Spring 2007). Marc Flandreau is grateful to Carlos Medeiros (then head of IMF's Capital Markets division) for exchanges that proved very helpful at an early stage of this research and to the IMF for hospitality when several of the ideas in this paper took shape. We thank Sara Bertin (then at Moody's), Michael Dicks (then at Lehman Bros) and Javier Santiso (OECD) for sharing with us their lists of contacts and insights. Excellent research assistance from Thomas Dickinson in interviews in NY is also acknowledged. Authors are also grateful to bank archivists in London and Paris for providing them with generous access to an incalculable number of boxes and material and to the Librarian at the Graduate Institute Yves Corpataux for help and support. Thanks to Vincent Bignon for a careful, speedy, and expert feedback on the pre-first draft. Thanks to Lucrezia Reichlin and Ken West for the invitation. Thanks finally to Vincent Reinhart for comments, suggestions and challenges.

- Marc Flandreau is Professor of International Economics, Professor of International History and Politics and Associate Professor of Development Studies at the Graduate Institute of international and Development Studies in Geneva, and a research fellow at CEPR. Juan H. Flores is Assistant Professor in economic history, University of Geneva. Norbert Gaillard is Post Doctoral Fellow at Sciences Po, Paris. Sebastián Nieto-Parra is economist at the Development Centre, OECD, Paris.
} 
Wow. I hadn't thought of it through a historical perspective. John Grisham, The Partner, 1997, p. 452.

In the past twenty years dedicated research efforts have helped us expand our knowledge of the operation of the international financial system. Because the emergence of global finance is really re-emergence, a large fraction of this research has been devoted to understanding previous regimes and experiences in relation to modern ones. While matters are hardly settled and controversy is vibrant there is at least now a body of literature to which we can turn. We know much more about the record of international debt than we did thirty years ago. We have acquired knowledge on how previous bondholders have fared. ${ }^{1}$ We have acquired knowledge on the incidence of collective action institutions on recovery rates. ${ }^{2} \mathrm{We}$ have acquired knowledge on debt crises and bond prices volatility. ${ }^{3}$ We have acquired knowledge on contagion in the long run. ${ }^{4}$ We have acquired knowledge on the factors that affected countries' reputation. ${ }^{5}$ We have acquired knowledge on the historical determinants of sovereign bond prices in secondary markets. ${ }^{6}$ We have acquired knowledge on the historical incidence of exchange rate regimes on credibility - or lack thereof. ${ }^{7}$ Last, we have acquired statistical knowledge on the long run evolution of government debts. ${ }^{8}$

One area has been under-researched in comparison. It pertains to the microeconomics of foreign currency sovereign debt issuance. Macroeconomists recognize that the workings of primary international capital markets are important because these markets provide countries with access to external funding. ${ }^{9}$ Yet the nuts and bolts of their operation are usually neglected despite some occasional outburst of interest for certain special feature with policy relevance. A prominent example has been earlier research on the causes and consequences of the so-called original sin phenomenon..$^{10}$ The relevance of some more arcane aspects of debt

\footnotetext{
1 . Eichengreen and Portes (1986); Lindert and Morton (1989).

2 . Eichengreen and Portes (1989).

3 . Bordo, Eichengreen, Klingebiel and Martinez-Peria (2001), Mauro, Sussman and Yafeh (2006).

4 . The most significant contributions include Bordo and Murshid (2000) and (2002), Kaminsky and Reinhart (2000), Kaminsky, Reinhart and Végh (2003), Mauro, Sussman and Yafeh (2002) and (2006), Neal and Weidenmier (2002), and Flandreau and Flores (2009).

5 . Flandreau (2003); Tomz (2007). See also Flandreau, Gaillard and Packer (2009) for the emergence of ratings in the interwar.

6 . See Flandreau, Le Cacheux and Zumer (1998) for an early contribution. Subsequent works include Flandreau and Zumer (2004) and Mauro, Sussman and Yafeh (2006).

${ }^{7}$. See Bordo, Edelstein and Rockoff (1999) and Flandreau and Zumer (2004) for dissenting views.

8 . Flandreau and Zumer (2004) for the late $19^{\text {th }}$ century and Reinhart and Rogoff (2009) for longer time periods.

9 . Eichengreen and Mody (1998); Grigorian (2003); Gelos, Sahay and Sandleris (2004); Fostel and Kaminsky, (2007). Other papers relate to (mostly descriptive) aspects of issuing costs for certain countries (see Zervos, 2004).

10 . "Original sin" refers to the observed tendency to denominate external debt in foreign currency (see Eichengreen and Hausman 2005). For historical aspects of the matter, see Flandreau and Sussman (2005).
} 
issuance has also been acknowledged. We have in mind studies on the incidence of certain covenants such as Collective Action Clauses on bond prices. ${ }^{11}$

This paper is the first to take up the issue of the operation of primary markets over the long run. We identify an intriguing result. Using new data on several episodes of foreign currency sovereign debt issues in leading capital markets and organizing the output according to the identity of the underwriter, we find that defaults are today randomly distributed across underwriters. But they were not in the past. This is what we call the default puzzle.

Resolution of this puzzle requires introducing in the discussion insights from banking theory. Our interpretation hinges on the effects of brand or charter value on intermediaries' risk taking. In the past "era" (meaning the long run period that started in the early $19^{\text {th }}$ century and ended up with the interwar crisis) underwriters provided valuable certification services. They tried to secure prestige by convincing investors their name was associated with safer products. The reason why they did this was not honesty, altruism or self-esteem, but because this entailed benefits. Today is different. Underwriters have shed their role as certifiers and outsourced it to rating agencies. The reduction in liability risk also means that more competitive banks are prepared to issue riskier securities. We suggest that this new situation has given birth to a market for lemons, which did not exist in the past. We conclude that the next sovereign debt Tsunami will run on a foreign currency debt market that is by design more accident prone than its predecessors. Whether we hold adequate tools to tackle it remains to be seen.

To support these claims, we marshal a large amount of new data. Unlike important and ambitious previous works we draw not only on published sources but on archives as well. We have also performed interviews. This reliance on primary evidence (archives and interviews) is required given the sometimes secretive nature of the business under study. As a result, this paper is the first to deal with the operation of primary markets for foreign government debt over such a long time span. With the help of this new evidence, we are able to test our central argument, through a number of its implications. Among our findings, we report a change in the degree of concentration in the underwriting business (highly concentrated in the past, much less now), in the underwriting services provided (encompassing in the past, much more limited now), on the fees collected (large and increasing with risks in the past, small and irresponsive to bond spreads now), on the quality standards that market leaders applied (high

\footnotetext{
11. See Eichengreen and Mody (2000); Gugiatti and Richards (2003) and Becker, Richards and Thaicharoen (2003) for different perspectives.
} 
in the past, low now), on the cooperation between underwriters and borrowers (strong in the past, limited today) and finally on the quality outlook of the products brought to the market (the past did not have a large market for products below the Investment Grade threshold, the present does).

The remainder of the paper is organized as follows. Section I presents the data, the puzzle and a sketch of the argument. The other Sections provide various tests of our theory. Section II discusses measures of market concentration. Section III provides evidence on underwriting patterns and fees levied. Section IV discusses relation between underwriters' brand value and risk taking. Section V provides evidence on the link between underwriting and contagion. Section VI explores the link between banker turnover and reputation. Section VII shows that the modern period has been characterized by the emergence of riskier debt. Section VIII discusses the reasons for the regime change in the modern era. We end with conclusions.

\section{Section I. The Default Puzzle}

\section{Background and data}

In the $19^{\text {th }}$ century, lending to foreign governments occurred through the agency of originating houses located in the leading financial markets of the time. Since these houses had subsidiaries or partners in various cities the diffuse nature of origination was a characteristic feature of the business. London was the leader in that it was home to a large number of underwriters and issues, but Paris emerged as a serious competitor towards the late $19^{\text {th }}$ century. ${ }^{12}$ During the interwar period, the center of the world financial system partly shifted to New York and government securities followed..$^{13}$ After an extended period of suspension coinciding with the period between the bonded debt collapse of the interwar and the banking debt debacle of the early 1980s, this market has been reinvented along lines, which at first sight appear broadly similar. ${ }^{14}$ This market relies on international securities originated and distributed by investment banks. This market has prospered since then. The emerging markets crises of the 1990s and their boom during the period 2002-2007 have been its latest vicissitudes. An open question at the time we are writing is the resilience of foreign country debt in the wake of the sub-prime crisis and global recession and high CDS premia.

\footnotetext{
12 . Jenks (1927), Landes (1958) and Gille (1965) and (1967) provide classic accounts.

13 . Lewis (1938). Roberts (1992) describes how certain London houses opened shops in New York to remain in the game.

${ }^{14}$. We leave out the experience with syndicated lending which was very different from present and earlier arrangements as it served to allocate bank debt and thus differs radically from the "originate and distribute" set up. In particular, this market involved international financial institutions that were all "informed" and who kept the credits on their books.
} 
In what follows, we deal with foreign government debt issued in leading financial centres in the past 200 years. Our database comprises issues of foreign governments' debts since the beginning of the $19^{\text {th }}$ century. We look at the London (1818-1914), Paris (1882-1914) and New York (1920-1930). We look at the foreign government debts placed abroad of "emerging" and "transition" countries during the "present" era (1993-2007). Our data is not a series of "samples" but rather as far as possible, the documented population of issues. ${ }^{15}$ The historical material is constructed from listings of securities issued in the relevant markets, checked against lists found in bank archives and periodicals. The modern material includes the population of issues that form the background for the "League Tables" published by Bloomberg. ${ }^{16}$

One issue that arises is the comparability of "emerging" and "transition" governments over time. Previous research has generally brushed this issue away and considered that $19^{\text {th }}$ century borrowers such as Denmark, Sweden or Canada are adequate counterparts for modern emerging countries. ${ }^{17}$ Such an assumption may be questioned. ${ }^{18}$ Because colonies were really sub-sovereign entities, they have been excluded from this study and our focus is on sovereign emerging and transition now and sovereign borrowing in foreign currency then. On the other hand a strict comparability may have required adding more well-behaved countries in the modern dataset than we do.

Our logic is market based not fundamentals based (the latter would be quite impossible to implement). In other words, we compare market to market. To the extent that producers of League Tables and market participants describe emerging and transition countries debt as forming a market, it is natural to try and match it against a historical counterparts. Previous periods did not recognize such differences and looked at the foreign currency government bond markets as a whole: the fact is that it did contain predominantly the securities of countries without a large domestic market. Second, we noted a fair amount of continuity in the identity of the countries involved in various episodes (Russia in the $19^{\text {th }}$ century and today is an example that comes to mind). Finally, we strongly believe that our basic findings would be robust to the inclusion in the modern group of safer borrowers, because our key point is about transformations in the high-risk group, not about transformations in the low risk category.

\footnotetext{
15. Appendix 1 gives description of data sources.

${ }^{16}$. More precisely, we focus on securities that are taking into account for league table purposes. See Bloomberg Markets (2006).

17 . See Mauro, Sussman and Yafeh (2006) for a study that proceeds in this spirit.

18. See Accominotti et al. (2008).
} 
The chronology we focus on does capture the successive waves of sovereign debt issues that have taken place since the 1820s. We identify six. Historians have shown that the first five were terminated in more or less abrupt ways: The early $19^{\text {th }}$ century $(1818-1829)$, the mid-19 $9^{\text {th }}$ century episode $(1845-1876)$, the 1880 s $(1877-1895)$, the pre-WWI period (sometimes inappropriately called the "first era of globalization"), the 1920s (1920-1930) and finally the modern era (1993-2007). Three of these waves (the $1820 \mathrm{~s}$, the mid-19 ${ }^{\text {th }}$ century, and the interwar period) were terminated by massive failures. Because of this, they will receive more detailed attention. In the rest of the paper these periods will be referred to either with the help of the time brackets listed above, or in short hand as then/early $19^{\text {th }}$, then/mid$19^{\text {th }}$, then/1880s, then/pre-WWI, then/interwar, and now, respectively.

The Puzzle

Defaulting countries are usually studied from the point of view of their characteristics or fundamentals and accordingly an exciting literature has sought to relate default probabilities to countries' performance. ${ }^{19}$ Previous authors identified defaulting patterns and coined the expression "serial defaulters" to designate recidivists. ${ }^{20}$ We suggest here to take a different look. We bring a new dimension to the study and suggest looking at defaults conditional on the identity of underwriters. The importance of common lenders has been recognized in previous studies of contagion, who emphasized commonality of lending centers as a possible propagation mechanism. We bring the topic to a finer level and explore the relation between borrowers and underwriters. ${ }^{21}$ Our first question is to ask whether defaults across underwriters can be described as generated from a random draw or whether instead underwriters do or did specialize in certain kinds of securities. ${ }^{22}$

For this purpose we compare the distribution of defaults per underwriters during the modern era and earlier periods. A formal Chi-square based criterion is Cramér's V statistic (Kendall and Stuart, 1979). We computed it for three selected episodes of major sovereign

\footnotetext{
19 . See e.g. Goldstein, Reinhart, and Kaminsky (2000), Demirguc-Kunt and Detragiache (1999), Kaminsky and Reinhart (1999), Berg and Pattillo (1998), Corsetti, Pesenti, and Roubini (1998), Demirguc-Kunt and Detragiache (1998), Kaminsky (1998), Goldfajn and Valdes (1997). A recent addition to this literature is NietoParra (2008) who shows that fees paid to underwriting banks have an explanatory power for predicting sovereign crises.

20 . Reinhart and Rogoff (2004).

${ }^{21}$. For empirical evidence on this argument, which has often been mentioned (see e.g. Calvo 1998), see Kaminsky and Reinhart (2000) and Van Rijckeghem and Weder (2003).

${ }^{22}$. A related question was considered by Mintz (1951) who emphasized heterogeneity in default rates during the interwar.
} 
debt distress (the 1820s, 1870s and 1930s) and for today. ${ }^{23}$ The output is presented in Figure 1. We see that there used to be a clustering of defaults with certain intermediaries (in the past, defaults were not random), while this is no longer true today (nowadays, defaults are randomly distributed). ${ }^{24}$ This intriguing result means that in the past, the identity of underwriters provided information on the likelihood of future defaults while this is no longer true. We call this the default puzzle.

\section{Suggested Resolution}

Can we make sense of this puzzle? The argument we put forward builds on theoretical insights from banking and finance theory but also extends ideas first articulated in Flandreau and Flores (2009). The argument has parallels in the classic paper by Diamond (1989) on the importance of repeat play in sustaining credibility. Since repeat play alone cannot sustain sovereign debt, Flandreau and Flores (2009) interact it with underwriters' monopoly power. The intuition is related to Chemmanur and Fulghieri (1994) who develop a relevant model in which financial intermediaries' reputation for veracity mitigates the moral hazard problem in information production. Prestigious underwriters who might be tempted to overprice securities in order to generate short-term gains do not do so because it would damage their reputation. Carter, Dark, and Singh (1998) show that over the long run, issues managed by prestigious houses outperform those managed by ordinary ones. Beatty and Ritter (1986) also show that underwriters whose offerings under-perform lose market share. Market share emerges as the endogenous solution to pre-commitment and credibility problems. As a result, natural monopoly emerges as a separating equilibrium in which quality, commitment, performance, and monopoly power are related to one another.

To see how these insights provide a way to think about the default puzzle, compare the two following regimes. In both regimes there are informed (intermediaries) and uninformed agents (investors). In the first regime (which we argue coincides with earlier times) informed underwriters combine liquidity provision (they help with the issue of bonds) and signalling

\footnotetext{
${ }^{23}$. Defaults reached close to $40 \%$ in the three episodes. They are close to $10 \%$ for the modern era. The proportion may rise substantially in the near future if we are believe current CDS premia for some emerging countries. Computations by Reinhart and Rogoff (2009) suggest that the selected episodes were the most violent in history.

${ }^{24}$. Given the sheer difference in the size of the two populations (the number of observations for the $1820=23$. $1870 \mathrm{~s}=180.1930 \mathrm{~s}=124$. Now=1442), straight comparison of Chi-square is not adequate. Cramér's V controls for that by dividing with number of observations and tests the strength of the association between the defaults and intermediaries. For the 1820, Cramér's V=.93. 1870s=.73. 1930s=.69. These numbers (above .7) are conventionally interpreted as revealing strong association (here between default and underwriters). By contrast, we find Now=.20. A value between 0 to .25 is usually interpreted as indicating a non-existent to weak association.
} 
services. In the second regime by contrast, the provision of liquidity and the signalling of quality are separated. Underwriters only concentrate on issuing as many bonds as they can. Certification has been delegated to rating agencies who provide advice to investors.

We can readily see why intermediaries' behavior will vary between the two regimes. The first regime provides an opportunity for certain underwriting banks to invest in prestige. Securing a reputation as a serious underwriter can become a source of rents because higher quality securities have a broader market. This can be used to attract the best borrowers and retain the initial monopoly position. Therefore we expect such a regime to display monopoly power, strong relationships between top underwriters and issuers, cherry picking by the best underwriters, and finally a tendency for lower grade securities to have a weak capacity to find a market. This is because the market for speculative bonds is operated by those underwriters with the weakest ability to certify (lemons problem).

In the second regime, availability of certification provision outside underwriters' certification does reduce revenues from underwriter certification. If everybody knows the "true worth" of a security, the marginal benefit of additional signals declines. We expect financial intermediaries to compete more aggressively. Underwriters make more indiscriminate choices when picking securities. The portfolio of securities that hits the ground is of lower average quality than under the other regime. In the end if certification has been outsourced, underwriters escape liability risks. Investors are now told about the risks and encouraged to diversify it away. The result is the emergence of a "market for lemons".

\section{Section II. Market Power}

Our view that earlier regimes rested on underwriters based certification implies we ought to observe more market power in earlier periods. In Table 1, we organize some hard evidence on the degree of competition that prevailed during successive episodes. Working with the sources described in the appendix, we constructed new statistical measures of market power. The first measure we discuss is the Herfindahl-Hirschman Index. Recall that an index below 1000 is associated with an un-concentrated market. Between 1000 and 1800 it is a moderately concentrated market. Above 1800, the market is highly concentrated. The second measure is the market share of the top three underwriters.

Table 1 shows the H-H index fluctuated over time but the overall degree of concentration was typically higher during earlier periods. The highest degree of concentration is for the mid $19^{\text {th }}$ century, interwar and late $19^{\text {th }}$ century Paris market (close or above 1800). Computation 
for the early period (1820s) also reveals that concentration was very substantial (H-H index of 1667). Concentration for the 1880 s and pre-WWI period was more moderate (1200 and 1270 respectively). The lowest degree of concentration is obtained for the modern period (New York and London) for which indices are slightly above or below 1000, with an aggregate concentration of 840 only.

We also computed market shares for the top three underwriters. Again, we find that the top three underwriters always controlled more than $50 \%$ of the market in historical time periods while this proportion is now below $50 \%$. Peaks correspond to the early $19^{\text {th }}$ century (London) late $19^{\text {th }}$ century (Paris) and interwar period (New York), which are all above 65\%. The low ebb is observed for New York and London today (48\% and 38\% respectively). So again market power is substantially lower today.

Finally, Figure 2 (a to e) ranks underwriters' market shares in various episodes. A striking feature is the decline over time of the leader's share, and the reduced difference now between the leader and her immediate followers. In the 1820s, Rothschild had $40.8 \%$ of the amounts loaned in London while the next intermediary (B. A. Goldschmidt) had 23.6\%. During the interwar, JP Morgan concentrated 50.8\% \% of the New York market while the next best (National City) had 9.9\%. JP Morgan still leads the New York market now, but with $20.8 \%$ only and the next best (Citi) is close behind with 15\%. The market for underwriting foreign government debts was highly concentrated until the interwar, but has become much more competitive as of late.

\section{Section III. Good Girls Go to Heaven, Bad Girls Go Everywhere}

We now examine two more predictions of our theory. First, if prestigious underwriters did worry about retaining market share but do not today, we should observe that they used to "cherry pick" better securities and are much less discriminating today. Evidence of this is provided in Figure 3.a and b. The Figures compare the ex ante quality of the portfolio of securities underwritten by the leading intermediary with the portfolio of the other firms. "Quality" is measured looking at the distribution of spreads (Evidence from ratings when they are available provides similar results). As can be seen, a striking difference between Figure $3 \mathrm{a}$ and Figure $3 b$ is that the interwar leader specialized in higher quality securities while the modern leader tends to issue similar or worse securities than followers. Figure 4 provides evidence of the average yield brought out by the "best and the rest" in a number of time periods. As can be seen, until the interwar, the best always issued safer securities than the rest. 
The other test we consider looks at ex post results. Suppose serious underwriters make careful choices to protect market shares. We should expect problems (measured here by default events) to concentrate within the lower end comprising less prestigious houses, which are also the ones with the smallest market shares. ${ }^{25}$ A convenient tool to capture this is to construct "Lorenz curves" of underwriters' performance. Ranking intermediaries' market shares from the smallest (small prestige) to the highest (high prestige) and plotting the cumulated share of underwriters' securities in default (in the total amount in default) helps study underwriters' risk taking. To see this let us define $\left(x_{k}, d_{k}\right)$ the pair formed by the amount underwritten by bank $k\left(x_{k}\right)$ and the defaulted amount previously underwritten by bank $k\left(d_{k}\right)$. Indices $k$ are set by ranking banks according to size in underwriting:

$$
x_{1}<\ldots<x_{k}<\ldots<x_{n}
$$

The cumulated market share $X_{k}$ for banks with smaller market shares than $k$ is :

$$
X_{k}=\frac{\sum_{i=1}^{k} x_{i}}{\sum_{i=1}^{n} x_{i}}
$$

The cumulated default share $D_{k}$ for banks with smaller market shares than $k$ is :

$$
D_{k}=\frac{\sum_{i=1}^{k} d_{i}}{\sum_{i=1}^{n} d_{i}}
$$

Finally the Lorenz Curve of underwriters' performance is therefore defined by the pairs $\left(X_{k}, D_{k}\right)$.

Suppose now that underwriters do not worry about what happens to the securities they have sold. Then default is random: the smallest underwriter with, say $5 \%$ of the securities underwritten will have about $5 \%$ of the defaults; combined with the next larger who has say $10 \%$ of the market, they will get about $15 \%$ of the defaults, and so on. The resulting Lorenz curve should therefore be close to the $45^{\circ}$ line. Suppose by contrast that prestige does confer a larger market share but requires to market good securities only (otherwise prestige would be lost). In this case the smallest (less prestigious) underwriter with $5 \%$ of the securities

\footnotetext{
${ }^{25}$. We are aware that default does not mean irrecoverable capital losses as previous research has demonstrated. Yet it provides a simple, straightforward way to capture the number of "problem cases" and is thus a valid indicator of performance.
} 
underwritten will have much more than 5\% of the defaults (say 20\%). By contrast the largest (most prestigious) underwriter with say $20 \%$ of the securities underwritten will have say, only $5 \%$ of the defaults. The resulting Lorenz curve should therefore be concave.

To test for this we consider four episodes (Figure 5). As before, the "past", is represented by the three most violent historical debt crises in history (1820s, 1844-75 and 1920-30). We compare this with the modern period. We find the three historical episodes to be associated with strong concavity of Lorenz curves. This contrasts with the modern set up for which the Lorenz curve essentially overlaps with the $45^{\circ}$ line. This is consistent with our view that the reason why default was not distributed randomly in the past while it is now is because underwriters used to make careful choices.

\section{Section IV. Fees and Risk Taking}

That underwriters were more heavily involved in the past than they are today should imply that, other things being equal, they took more risks aboard and required substantially larger fees than they do now. To show this we first summarize qualitative evidence we obtained from examining a large number of early underwriting contracts and interviewing modern market participants, then move to provide new data on the long run evolution of underwriting fees.

\section{Underwriting contracts, past and present}

Today, a key aspect of an international bond issue is the "agreement" between the main underwriter and the government. This document specifies the particulars of the issue such as the bond structure. One central aspect of the agreement is the "distribution system". In principle distribution could take the form of either "best efforts" or "firm commitment" - two forms that are known in other segments of the capital market. Under best efforts, the intermediary pledges to help selling many bonds as possible but does not bind itself to acquire any if there are no buyers. That is, a failed issue creates no liability. By contrast, in a "firm commitment" arrangement, the financial intermediary agrees to purchase all securities directly from the issuer for sale to the public and is liable for any unsold inventory. Interviews with market participants suggested that "best efforts" is the ruling pattern today. ${ }^{26}$

In the past, the contract signed between governments and underwriters was also a central part of the process and we have examined many. Like today, the main alternative was between having the underwriter as mere distributor of the bond or full insurer of the success of the

\footnotetext{
${ }^{26}$. For instance JP Morgan told us "everything is best efforts, rarely a firm commitment. Best efforts is the standard" Moreover according to Lehman Bros, "banks would never put up capital to buy a whole deal, enough to make a firm underwriting. You are not really paid to take that risk today".
} 
issue. The former arrangement was known as "sale on commission" and the second as "firm taking". These are equivalent to the modern best efforts and firm commitment systems: With sale on commission, underwriters received subscriptions for the purchase of bonds but took no liability in the result of the issue. ${ }^{27}$ With firm taking, the issue was understood to be purchased from the government and then resold to the public. Mixed arrangements involved partial commitment with a portion sold on commission. ${ }^{28}$

From the contracts we could examine, we found that firm taking became the dominant pattern over the nineteenth century, although there were periods and countries for which a greater proportion of sales on commission was observed. It is fair to say that by the end of the $19^{\text {th }}$ century, full or quasi-full underwriting had become a kind of more or less absolute norm. There were some exceptions however. We found that Barings initially favored sales on commission. Testifying in 1875, one Baring employee drew a sharp contrast between issues where they acted as genuine "contractors" (underwriting the issue) and issues where they would be mere "agents" (only placing the loan in the market) adding that "most generally loans are issued by the firm [i.e. the Barings] in London as agents for the Government" (Select Committee, p. 1: our italics). ${ }^{29}$ This declaration is consistent with the actual Baring contracts we could inspect. Over time, however, even the Barings moved to full underwriting.

The same pattern (i.e. predominance of the full underwriting contract) does apply for the interwar period as well. The Senate Committee hearings provide much evidence that this was the case in the New York market during the interwar period. British bankers examined before the Macmillan Committee in 1931 also emphasized it. Sir Kindersley (of Lazard) made a distinction between a "bank" or mere distributing institution and a "issuing house" or genuine originator and underwriter and emphasized the importance of actually buying the securities it distributed. "Q. 1302. Do you buy up the issue yourselves? - Yes. I think that another

\footnotetext{
${ }^{27}$. The limited role of the bank in the sale on commission is described in the following way by White (of Barings) examined by the Select Committee: "Q 64 : What is it that you do for that ; what is it you are bound to do for that commission? - We are bound to make all the arrangements for issuing the loan. Q 65: What sort of arrangements; suppose the agreement made, what do you do? - We examine all the documents, and prepare the prospectus, and invite subscriptions for the loan; then we issue scrip for the loan, then receive the proceeds generally by various instalments [sic]; and when all this is completed we receive the bonds and countersign them, and issue them to the public" (Select Committee, p. 3).

${ }^{28}$. For a model studying the trade-off between underwriting share and commissions, see Flores (2007).

29 . The Committee was concerned with the way information about underwriters of the loan would be conveyed to the market. "Will you tell me, please, would that prospectus show the contractors for the loan; assuming Messrs. Baring to have contracted with the Russian government, or any other Government, would their name appear as contractors upon the prospectus? - Yes. But in many cases loans are issued simply by the firm in London as agents for the Government and not as contractors for the loan. Most generally loans are issued by the firm in London as agents for the Government". At a later stage of the interview White added that he knew of only "one instance of a loan which has come under [his] control which was not issued on commission" (p. 2).
} 
difference between an issuing house and a bank is that an issuing house, not always, but I think in the majority of cases purchases the security and re-sells it to the public. It takes the definite risk and purchases it ... This is what generally happens". ${ }^{30}$ To use the language of Kindersley, modern intermediaries are more like "banks" than "issuing houses". The prevalence of a more coercive business norm in the past is further supportive evidence of our central claim.

\section{Fees and risk taking}

Can we provide some numbers to match our suggestions from qualitative evidence? Table 2 gives ranges for fees. Sources (archival or other) are indicated in footnotes. The first two columns report the proportion between fees and spreads for the sub-sample of securities for which we do have material. This ratio is computed for the dominant underwriting pattern (best effort for the modern period and full underwriting for earlier times). The Table does support notions that emerged from earlier discussion. The ratio between fees and spreads used to be much larger in the past. It has massively declined in more recent periods, which is consistent with our finding of a more limited underwriting service today.

One may worry that part of the result is driven by technological progress making modern underwriting more efficient. We are skeptical of this, however. Most of the revenues from underwriting must come from the risks involved (captured by underlying volatility) for which division by spreads controls. But to address this concern, Table 2 also decomposes the available evidence, reporting minimum, maximum and average fees according to alternative underwriting regimes. ${ }^{31} \mathrm{We}$ find that earlier times' best efforts charges were not very different from modern ones. While they were somewhat larger on average, they did not fall outside the modern range. This leads us to conclude that technological progress cannot account for the decline in fees. Instead, we explain it by the reduced scope of underwriting services now. The real transformation is the changeover from one business norm to another.

Further evidence on the matter can be garnered by looking at the correlation between spreads and fees. As said, under firm commitment, the intermediary takes all the risk of the

\footnotetext{
${ }^{30}$. Our italics. Macmillan Report, Minutes of evidence, p. 77-8.

31. Specifically, we have tried to identify the charges that were paid in the cases when the alternative system was chosen. While we have no evidence of modern contract with full underwriting, there are some cases of best effort contracts in the past. First we have the Barings contracts already alluded to. Next we have contracts that coincide with "conversions" (whereby debts were swapped against new ones with lower yields). Underwriters bore no substantial risk (although unhappy investors could in principle ask for a refund) but had to prepare the market, talk to investors, explain the particulars of the new bond, etc., somewhat like what underwriters do under "best efforts". Another way to measure the value of distribution is to split when this is feasible the distribution (or placement) part from the underwriting contract.
} 
issue and this risk is related to the volatility of the bond. ${ }^{32}$ We should thus expect a stronger association between spreads and fees in the past than now. ${ }^{33}$ Results are shown in Table 3 . We find substantially higher correlation coefficients in the past. Another test in Table 3 provides a way to examine the significance and sensitivity of fees to spreads under different regimes. We run a simple OLS regression of fees on spreads, plus a constant. We find higher significance and sensitivity, higher R2's as well, in the past. This is consistent with a bigger pass-through of country risk into underwriting fees and again indicates less risk taking by financial intermediaries today.

\section{Section V. The Evolution of Contagion}

Another implication of our analysis is that serious underwriters ought to take special care to make sure that their sponsored issues turn well, because their reputation is at stake. In other words, the concavity of the Lorenz curve discussed earlier is a primary concern for them. There are various ways to test for this. One is to look at whether banks are involved in secondary markets. Brand conscious underwriters ought to worry about excess volatility or contagion spilling over to "their" securities. Accordingly they should intervene to prevent such events.

Interviews with modern bankers suggested that today underwriters offer some partial participation in the secondary market. However, the underwriter is typically not obliged to make a secondary market for the bonds, consistently with best effort contracts. ${ }^{34}$ The responsibility of underwriters is thus limited to place the bonds in the market and make an effort to stabilize the price of the bonds in the secondary market during an unspecified time. It is never understood that the underwriter should act as lender of last resort of the bonds issued by governments. ${ }^{35}$

\footnotetext{
32 . Interpreting the underwriting service for the issuer as an insurance premium, Appendix 2 shows that under firm commitment contracts, fees are an increasing function of spreads.

${ }^{33}$. Note that recent research provides conflicting results on the modern relation between fees and yields. Amira (2004) finds such an association for (corporate) Eurobonds. Nieto-Parra (2008) reports weak evidence of this correlation for modern emerging market sovereign debt.

${ }^{34}$. Consider the following excerpt from the prospectus of a Brazilian loan issued in 2004: "No assurance can be given as to the liquidity of the trading market for the global bonds". Prospectus supplement of US $\$ 750,000,000$. Federative Republic of Brazil. 10.5\% Global Bonds Due 2014. July 7, 2004. Some interviewees reported that this service is related to the fee paid to the underwriter and to the underwriter's willingness to acquire a reputation as a good supporter, increasing the likelihood to secure future contracts

35 . This is unlike the underwriting services occasionally provided to emerging government bonds by multilateral organizations, such as the World Bank (WB) or the Andean Development Corporation (CAF) who do include commitments.
} 
In previous eras, underwriters frequently engaged in market operation to support the government bonds they were issuing and these purchases went way beyond the initial issue and placement of the bonds. Such operations occasionally came up in the press or in parliamentary commissions in reference to "fictitious" operations to "inflate" bond prices and they could be in some cases. ${ }^{36}$ As a result, bankers sometimes denied they were involved in such schemes. ${ }^{37}$ However leading houses acknowledged their role as lender of last resort. Rothschild's testimony before the Select Committee is an example. ${ }^{38}$ Flandreau and Flores (2009) report evidence of massive purchases of Rothschild sponsored securities during one episode of financial contagion in the 1820s. Kahn (from the firm Kuhn and Loeb) testimony before the Senate Committee in 1931 recognized the existence of support purchases and added that underwriters were under "permanent moral liability" to make ends meet. As he stated: "we have frequently made it our business, a contingent part of our obligation, that if there is an undue or unjustifiable decline in bonds, if there is not a fair market for the bonds, we have more than once gone into the market in order to afford the opportunity to such people as may want to sell, or are compelled to sell, within the limits of proper prudence, and within the limit of our ability, for them to do so" 39

Table 4 reports relevant data to bear upon this issue. Namely we have organized figures on past and present markets looking at monthly bond spreads in sterling bonds (1820s) and USD bonds (now). To enable relation with earlier work, the measure of contagion we use is that of Mauro et al. (2006) who identify sharp changes in bond spreads (measured as either 200 b.p. jumps or $20 \%$ changes) and look at commonality of these sharp changes across countries. We see that jumps are more frequent today, and contagion is comparable. The next stage is to sort out securities issued by the underwriter with the largest market share. That is, we isolate Rothschild securities and JP Morgan securities from the rest. While Rothschild specialized on a more limited number of countries (Austria, Brazil, Naples and Russia), JP Morgan has been underwriting all governments in the sample. In other words, there is no such thing as a JP Morgan security, or to put it differently, the JP Morgan portfolio is the market portfolio as we already reported. The "Non-Rothschild" and "Rothschild" columns drive our story home showing that all the contagion did cluster onto non-Rothschild securities. This we interpret as

\footnotetext{
${ }^{36}$. Members of syndicates, underwriters and brokers were said to engage in the promotion of similar bonds by forward market operations in order to whet the appetite of investors. This practice, called "market rigging" in the US, has often been frowned upon (Select Committee 1875, Jenks 1927: p. 276-8, Lysis 1908, Benston 1990).

37. An illustration is one Baring employee's testimony before the Select Committee Select Committee, p. $1 \mathrm{ff}$. This allegation does not stand against powerful evidence from Barings' own archive (Ziegler 1988, Flores 2004).

38. Select Committee, p. 267. See also Flandreau and Flores (2009).

39 . Senate Committee, p. 135.
} 
the combined effect of signalling of good securities by prestigious underwriters and underwriter's willingness to intervene to support "its" securities (to prevent deterioration of reputation). We conclude that good intermediaries were concerned with the performance of the securities they sponsored explaining why, in the absence of any contractual obligation, they nonetheless volunteered help. We see that this has been lost in today's markets. Our finding may go some way towards explaining the evolution of contagion over the long run.

\section{Section VI. Turnover and Reputation}

Another bit of evidence can be garnered by looking at turnover. The previous identification of a tendency for underwriters to band with issuers in previous eras should be reflected in some properties of turnover rates. Consider the following reasoning, applying to what we called the "past" regime: good issuers benefit from association with prestigious underwriters because such intermediaries are prepared to support them. Of course issuers get charged for this (we found higher fees then than now). Good issuers may want to bargain for better terms but on the other hand, going to lesser underwriters would make investors weary. And since by definition there are not many good underwriters turnover at the top should be small (if we consider that going down by more than one notch in the underwriting scale would entail reputational costs, the expected turnover is going to be limited to switching between the top two). By contrast, lesser issuers have an incentive to shop around because prestigious underwriters do not want to deal with them and because the other mediocre underwriters are substitutes for one another. As a result a greater turnover ought to be expected at the bottom. The implication for this is that for the past period, we ought to observe a positive correlation between turnover and spreads at issue, other things being equal.

As far as the modern market is concerned, we found it to be very competitive, with all underwriters doing pretty much the same thing. The implication is that a) average turnover ought to be more substantial (all issuers shop for the best prices) and b) we ought not to observe any correlation between turnover and spreads. Thus we get two more testable propositions of our theory. They are examined in Figure 6 which correlates on a country basis country turnover and average spread at issue. The Figure also permits a visual location of the "average" turnover (between 0 and 100\%). The periods chosen are the modern era and a longer chunk of time than in other tests (London 1877-1914). This is done in order to insure 
the statistical significance of turnover rates in the presence of less frequent market access then than now. ${ }^{40}$

The result in Figure 6 is striking. First it is obvious that average turnover has increased tremendously in the modern period. Computations show an average turnover of $51 \%$ for the historical period against $86 \%$ for the modern one. Second, we observe a positive association between turnover and spreads for the historical period. There is no such association for the modern period, consistently with our predictions.

\section{Section VII. The Market for Lemons}

The last proposition we examine is the following: if reduced asymmetries of information permits large underwriters to escape liability costs, then we should observe a transformation in the characteristics of the bonds that are issued today compared to earlier periods. While safer bonds that could make it to the market then should still be around now, riskier ones that had a harder time in the past are less penalized now and should feature more prominently. In other words, we argue that in the modern era a market for lemons is born.

To document this, Table 5 provides basic characteristics of the population of government securities that made their way to the market place at different time periods. We outline a number of basic measures. We report the number of securities that could be identified and then we give the number of countries that accessed the global capital market. The next column has data for the minimum, maximum and average size for the securities in the corresponding group and a conversion of these amounts in 2008 USD, using http://www.measuringworth.com/index.html to convert amounts. ${ }^{41} \mathrm{We}$ then report information on maturity and risk. Maturity is the time lag to the date of redemption as stated in the initial issuing documentation or the press. ${ }^{42}$ Risk can be measured by looking at either yield premium at issue or rating at issue. Because rating agencies only started sovereign debt assessment after WWI, this measure is only available since the interwar period onwards. ${ }^{43}$

\footnotetext{
40. Turnover is measured as the sum of underwriter switches divided by the number of issues. Where there are multiple underwriters, if any of the underwriters from the past issue are among the underwriters for the current issue, we do not consider this event as a switch. Because (as the next section will show) countries used to access markets with longer term securities than today and thus less frequently, the interwar period with its short boom and bust record is not a good benchmark and we have preferred using the last two periods of the 19th century (London market), for which a long track record (and thus reliable turnover rates) can be constructed (1877-1913).

${ }^{41}$. Conversions based on CPI. The year used is mid-period except for the first era for which 1830 was chosen. The Eh.Net site provides conversions for both sterling and USD. French francs were first converted in USD at the (fixed) exchange rate that prevailed at the time (gold standard).

42 . Actual redemption could be shorter and as we already discussed it was standard practice for loans to contain covenants permitting reimbursement or conversion before maturity.

${ }^{43}$. See Flandreau, Gaillard and Packer (2009).
} 
There are two features that emerge from the Table 5. The first is the shorter maturities in the modern period compared to earlier times. During the nineteenth century, average maturities lengthened gradually: they went from 31 (1818-29) to 33 (1845-76) to 47 (18771895) and finally 43 (pre-WWI). At about the same time (1880-1914) maturities were comparable in Paris (around 50 years). The interwar saw a substantial decline of maturities, but they were still above 25 years. This contrasts with the recent period, for which average maturities have been halved (NY) or divided by three (London). The modern average is below 10 years. This reduction in maturities has been noted before but its significance has not been explained. Theory suggests that restricting maturity of the debt facilitates control because it gives lenders a sanction over borrowers (Montiel, 2003). One possible interpretation of the evidence on maturities therefore, is that foreign debt is inherently riskier today than in the past.

The second intriguing fact has to do with the evolution of spreads. The shortening of maturities makes direct comparison of spreads difficult owing to upward sloping yield curves. Broner, Lorenzoni and Schmukler (2004) argue that today's emerging economies borrow short term due to the higher risk premium charged by international capital markets on longterm debt. As a result, counterfactual long term debt yield premia that would prevail if countries borrowed today as they did in the past might be higher than observed. With this qualification in mind, we see that average spreads are at least as high today as they were in the past implying that counterfactual long term rates might be substantially higher. Spreads declined over the $19^{\text {th }}$ century, from 357 and 397 basis points (1820s and mid century) to 275 (1880s) and 215 (pre WWI), then rose again during the $20^{\text {th }}$ century, standing at 291 in New York in the interwar and 364 for the same market in the modern period (average spread in London is $288 \mathrm{bps}$ ). Similar spreads associated substantially shorter maturities may thus be indicative of riskier debt.

Another piece of interesting information is provided by average ratings, which are indicated in Table 5 and detailed in Figure 7. To make comparisons across time periods possible, Figure 7 aggregates modern ratings to match earlier, coarser granularity (the appendix provides the details of how mapping modern ratings into earlier ones). Figure 7 outlines the Investment Grade/Speculative Grade cut off, which was already recognized in the interwar period. ${ }^{44}$ As can be seen in Table 5, the average rating for foreign debt was above investment grade during the 1920s (or an average A), but it now squarely within speculative

\footnotetext{
${ }^{44}$. In the interwar, the cutoff was Baa/Ba. Today it is Baa3/Ba1 (Moody's). See Flandreau et al. (2009).
} 
grade (an average BB for NY and BB+ for London). In Figure 7, we see that the speculative grade category was very narrow during the interwar while it is very broad today. In other words, a genuine liquid market for speculative grade government securities is born. IN the language of one interviewee from Alliance Capital who described for us the modern market: "Underwriters will underwrite anything, for a fee." We suggest that in the past reputable underwriters prevented riskier securities from reaching the market because of brand concerns.

\section{Section VIII. Regime Change}

This paper has outlined the contours of two successive certification regimes: the "older" one that rested on underwriters' signals and the new one, where underwriters have outsourced the certification service to rating agencies. One pending question is why this transformation occurred. Why was it that certification was outsourced to rating agencies? In what follows we review a number of arguments that may explain why underwriters shed their earlier role as gatekeepers of the quality of international government securities.

A natural explanation that comes to mind is progress in information technology. The insider knowledge of the "Rothschild era", the superior technology provided by pigeons or reliable correspondents, etc. would have become less important in today's world when information can run across continents at light's speed. Investors now learn about market prices in real time, governments are more open and transparent, they are more uniform in reporting etc. While these arguments must have played a role, they seem to lose significance in the face of the brutality with which the regime change occurred. After all, there have been radical changes in information technology between the 1820s and the 1920s. News that took weeks, days and hours to reach leading markets now came in seconds or fractions thereof. While the fractions have been again halved since the 1820s, the marginal change is much smaller. It is not clear therefore why, if technology is what matters, the interwar was so much like the early $19^{\text {th }}$ century, itself similar to the $18^{\text {th }}$ century, and so different from the modern era.

Another counter-argument to the technology view is that once a signalling regime of the kind that prevailed in the past is in place and performs well, there are no reasons to replace it. Incumbent have no advantage in a change of status quo and outsiders have no ability. In other words, we expect to see a fair deal of persistence in certification regimes, quite apart from the strict availability of information. Supporting this conjecture, we note the persistent leadership of the House of Rothschild in the $19^{\text {th }}$ century (it could only be displaced when the market 
moved to New York, where they had no presence), which occurred as pigeons were replaced by telegraph and word-of-mouth by The Economist's Investors' Monthly Manual. Similarly, Moody's, Standard Statistics, Poor's or Fitch ratings, which began during the interwar, did coexist with the "JP Morgan" certification regime which we identified above. In other words, the availability of information is one thing, but the fact that investors manage to coordinate on new ways to process it is another matter.

Following this line, a possibility we think worth considering is that when the new regime was put in place underwriters could not be credible certifiers any more. Between the collapse of the 1930s and the securitization of the 1980s (Brady bonds) there were about 50 years during which the international government debt market was a sleeping beauty. The account we got of the conditions under which this market was restarted does suggest that certification by underwriters was not credible. A senior manager from Moody's who shared with one of us his memories of the 1980s, suggested that sovereign ratings had to be reinvented in a rush because they were critical for booking and marketing purposes. We interpret this as meaning that since "Brady bonds" were designed to offload defaulted debts from the balance-sheets of international banks, the very same banks that had made the wrong choices could hardly be credible certifiers of government securities. Some other certification instrument had to be conceived. As a result, when the international government debt market woke up, the first things she saw was a rating agency, and it immediately fell in love with it (there would be crises later).

The investment banks that got involved in the new market probably welcome the transformation (they included reincarnations of interwar New York leaders such as JP Morgan or National City Bank). Of course fees were now smaller, but liability risk was also reduced. Rating agencies would be the new lightning rod for accusations of financial malpractice. The banks although undoubtedly informed would now be able to show to unhappy customers the grades given by (possibly less informed) rating agencies. Academic economists have lent support and blamed the agencies. ${ }^{45}$ Moreover, while the fees were reduced maturities were shortened and the frequency of market access events increased as a result. In addition the emergence of a new market for lemons increased the amount to be underwritten. The net effect may depend on the specific bank we are looking at, but we speculate that, if there was an individual profit in reverting to the old regime and signal one's worth by limiting investment to certain securities only, the industry would have already figured it out.

\footnotetext{
$\overline{45}$. Reisen and Von Maltzan (1999); Ferri, Liu and Stiglitz (1999).
} 
Additional factors that may have pushed towards the same direction include questions of ownership and control in investment banks. Both British style merchant banks and US style investment banks used to be private institutions, and the owners of the capital were keeping a close eye on the dealmakers (or originators). The agency problems created by the distribution of bonuses to investment bankers have naturally reinforced the need for external certification services. This explains why rating agencies have now become part of the regulatory and certification infrastructure, a role that they did not have in more distant times. ${ }^{46}$ In this context, the rise of the use of ratings in regulation and the transformation of private investment banks into listed companies are complementary transformations. Whether we are safer with underwriting and certification made by the same agent or split across various financial intermediaries remains to be seen.

\section{Conclusion}

In a nutshell, our finding is the following: In earlier periods, investment banks provided their customers on both ends (lenders and borrowers) with a vast array of services, acting as broker, and certifier, and lender of last resort when issues failed. Today, certification is in large part provided by rating agencies and underwriting banks perform the limited function of "making the market" for the issuing government. The result, we demonstrate, was considerably bigger fees in the past (as a share of the amount issued). One implication of this is that today's debt is by construction more risky and volatile than it was in the past. Moreover, this debt is certified by agents who do not have direct access to the flow of soft information normally obtained through underwriting and banking relationship. They must rely on published information only. Should trouble come, rating agencies have no means to help and no privileged information. Underwriters for their part have no reason to provide support because they escape liability insurance. By contrast, in the past, the issuer-certifier saw the wisdom of not jeopardizing her reputation and was more willing to provide Lending of Last Resort help.

While this evolution may have beneficial aspects (it enables high-risk countries to borrow when they were rationed out in the past) we speculate that it has brought in new risks. First, it may have weakened market discipline. Since underwriters have been able to pass on to others

\footnotetext{
46. See Flandreau, Gaillard and Packer (2009) for historical details. The recent past has seen rating agencies becoming important agents in new bond offerings. While their participation is not strictly needed in a legal sense, domestic or international prudential regulation, which do rely on ratings and place limits on the purchase of unrated securities, make them necessary. For instance, the Basel II regulatory framework penalizes unrated securities (BIS 2005).
} 
the liability of making wrong choices, they have also softened borrowing governments' incentives to make adjustments when needed. Second, the degree to which increased risk built into the system is manageable hinges critically upon the ability of investors to diversify. Yet whether diversification is feasible in the presence of large, correlated supply shocks is still to be seen. It is our contention therefore that this time is very different: it may, actually, be worse.

In a recent noted piece of professional self-introspection Acemoglu (2009) writes that among the several notions he felt the sub-prime crisis had destroyed one was that "our logic and models suggested that even if we could not trust individuals, particularly when information was imperfect and regulation lacklustre, we could trust the long-lived large firms - companies such as the Enron's, the Bear Stearn's, the Merrill Lynch's, and the Lehman Brothers' of this world - to monitor themselves and their own because they had accumulated sufficient reputation capital. Our faith in long-lived large organizations was shaken but still standing after the accounting scandals in Enron and other giants of the early 2000s. It may now have suffered the death blow." This paper does shed light on why such beliefs were found to be disappointing: we incorrectly hoped that the present would be more like the past. 


\section{References}

Accominotti O., M. Flandreau, R. Rezzik, and F. Zumer (2008), "Black Man's Burden: Measured Philanthropy in the British Empire, 1880-1913”, CEPR Discussion Paper No. DP6811, April.

Acemoglu D. (2009), "The crisis of 2008: structural lessons for and from economics", CEPR Policy Insight No.28, January.

Amaral S. (1984), “El Empréstito de Londres de 1824”, Desarrollo Económico, vol.XXIII, n.92.

Amira K. (2004), “Determinants of sovereign Eurobond yield spread”, Journal of Business Finance and Accounting, Vol.31, pp.795-821.

Annuaire Officiel des Agents de Change (various years), Paris.

Anuario Estadístico de la República de Chile, año 1925, v.VI, "Hacienda" (1927).

Basel Committee on Banking Supervision (2005), International Convergence of Capital Measurement and Capital Standards: a Revised Framework, November, Basel : BIS.

Beatty R. and J. Ritter (1986), "Investment Banking, Reputation, and the Pricing of IPO", Journal of Financial Economics, Vol.15, 213-32.

Becker T., A. Richards and Y. Thaicharoen (2003), "Bond restructuring and moral hazard: are collective action clauses costly?", Journal of International Economics, Vol. 61(1), pp. 127-161, October.

Benston G. (1990), The Separation of Commercial and Investment Banking, London: Macmillan Press.

Berg A. and C. Pattillo (1998), “Are Currency Crises Predictable? A Test”, IMF Working Paper No.154, Washington D.C.: International Monetary Fund.

Bloomberg Markets, “The Bloomberg 20 - The World's best-paid investment banks”, April 2006.

Bordo M., M. Edelstein and H. Rockoff (1999), "Was Adherence to the Gold Standard a 'Good Housekeeping Seal of Approval' During the Interwar Period?', NBER Working Paper No.7186.

Bordo M., B. Eichengreen, D. Klingebiel and M. S. Martinez-Peria (2001), "Is the Crisis Problem Growing More Severe?”, Economic Policy, April 2001. 
Bordo M. and A. P. Murshid (2000), “Are Financial Crises Becoming Increasingly More Contagious? What is the Historical Evidence on Contagion?", NBER Working Paper No.7900.

Bordo M. and A. P. Murshid (2002), "Globalization and Changing Patterns in the International Transmission of Shocks in Financial Markets", NBER Working Paper No.9019.

British Parliament (various years), British Parliamentary Papers, Westminster, London.

Broner F., G. Lorenzoni, and S. Schmukler (2004). "Why Do Emerging Economies Borrow Short Term?", MIT Working Paper.

Burdett's Stock Market Official Intelligence (various years).

Calvo, G.A. (1998), "Capital Market Contagion and Recession: An Explanation of the Russian Virus", Mimeo, College Park, Maryland, University of Maryland.

Carter R. B., F. H. Dark, and A. K. Singh (1998), “Underwriter Reputation, Initial Returns, and the Long-Run Performance of IPO”, Journal of Finance, Vol. 53, issue 1, pp. 285-311.

Chemmanur T.J. and B. Fulghieri (1994), "Investment Bank Reputation, Information Production, and Financial Intermediation”, Journal of Finance, 49, 57-79.

Clarke H. (1878), "On the debt of sovereign and quasi-sovereign states, owing by foreign countries", Journal of the Statistical Society of London, 41/2, pp. 299-347.

Corporation of Foreign Bondholders (various years), Reports, London.

Corsetti G., P. Pesenti and N. Roubini (1998), "Fundamental Determinants of the Asian Crisis: A Preliminary Empirical Assessment", Unpublished manuscript (New Haven, New York, New York: Yale University and University of Bologna, Federal Reserve Bank of New York and NBER).

Costeloe M. P. (2003), Bonds and Bondholders, British Investors and Mexico's Foreign Debt, 1824-1888, Westport: Praeger.

Dawson F. G. (1990), The First Latin American Debt Crisis. The City of London and the 1822-25 Loan Bubble, Princeton: Princeton University Press.

Demirguc-Kunt A. and E. Detragiache (1998), "Financial Liberalization and Financila Fragility", IMF Working Paper No.83.

Demirguc-Kunt A. and E. Detragiache (1999), "Monitoring Banking Sector Fragility: A Multivariate Logit Approach", IMF Working Paper No.147.

Diamond D. W. (1989), "Reputation acquisition in debt markets", Journal of Political Economy, Vol. 97, 4: 828-62. 
Dritsas M. (1993), "Foreign Capital and Greek Development in a Historical Perspective", Uppsala Papers In Economic History, WP No.10.

Eichengreen B. and R. Hausmann (2005), Other People's Money: Debt Denomination and Financial Instability in Emerging Market Economies, Chicago and London: University of Chicago Press..

Eichengreen B. and A. Mody (1998), "What Explains Changing Spreads on EmergingMarket Debt: Fundamentals or Market Sentiment?", NBER Working Paper No.6408.

Eichengreen B. and A. Mody (2000), "Would Collective Action Clauses Raise Borrowing Costs", NBER Working Paper No.7458, January.

Eichengreen B. and R. Portes (1986), "Debt and Default in the 1930s: Causes and Consequences", NBER Working Paper No.1772.

Eichengreen B. and R. Portes (1989), "Dealing with Debt: The 1930s and the 1980s", CEPR Discussion Paper No.300, February.

Ferri G., L.-G. Liu, and J. Stiglitz (1999), “The Procyclical Role of Rating Agencies: Evidence from the East Asian Crisis", Economic Notes, Banca Monte dei Paschi di Sienna SpA, No.3.

Fitch (various years), Fitch Bond Books.

Flandreau M. (2003), "Caveat Emptor - Coping with Sovereign Risk Under the International Gold Standard, 1871-1913", in Flandreau, M., C-L. Holtfrerich, and H. James (eds.), International Financial History in the Twentieth century. System and anarchy, Cambridge University Press.

Flandreau M. and J. H. Flores (2009), "Bonds and Brands: Foundations of sovereign debt markets 1820-1830", Forthcoming in the Journal of Economic History, Fall.

Flandreau M., N. Gaillard and F. Packer (2009), "Ratings Performance, Regulation and the Great Depression: Lessons from Foreign Government Securities", Forthcoming in BIS Working Paper.

Flandreau M., J. Le Cacheux and F. Zumer (1998), "Stability without a pact? Lessons from the European Gold Standard 1880-1913”, in Begg D. and al. (dir.), EMU: Prospects and Challenges for the Euro, Special Issue, Economic Policy (1998), pp.117-162.

Flandreau M. and N. Sussman (2005), “Old Sins: Exchange Rate Clauses and European Foreign Lending in the $19^{\text {th }}$ Century" in Eichengreen B. and R. Hausmann (2005), Other People's Money: Debt Denomination and Financial Instability in Emerging Market Economies, University of Chicago Press, Chicago and London. 
Flandreau M. and F. Zumer (2004), The making of Global Finance, Paris: OECD.

Flores J. H. (2004), Lorsque le leader suit la foule: La crise Baring dans une perspective microéconomique, Unpublished Diss. Sciences Po, Paris.

Flores J. H. (2007), "Lending Booms, Underwriting and Competition: The Baring crisis revisited", Working Papers in Economic History, Universidad Carlos III, 07-01.

Fortune's Epitome (various years).

Fostel A. and G. Kaminsky (2007), "Latin America's Access to International Capital Markets: Good Behavior or Global Liquidity?”, NBER Working Paper No. 13194.

Gelos G., R. Sahay and G. Sandleris (2004), "Sovereign Borrowing by Developing Countries: What Determines Market Access?", IMF Working Paper No.04/221.

Gille B. (1965), Histoire de la Maison Rothschild, Vol I: Des origines à 1848, Geneva: Droz.

Gille B. (1967), Histoire de la Maison Rothschild, Vol II: 1848-1870, Geneva: Droz.

Gille B. (1973), "Les Emprunts de Libération en 1871 et 1872", dans La France au XIXe siècle. Mélanges offert à Charles Hippolyte Pouthas, Paris, Publications de la Sorbonne, pp. 166-198.

Goldfajn I. and R. O. Valdes (1997), “Are Currency Crises Predictable?”, IMF Working Paper No.159.

Goldstein M., C. Reinhart and G. L. Kaminsky (2000), Assessing Financial Vulnerability: An Early Warning System for Emerging Markets, Washington D.C.: Institute for International Economics.

Grigorian D. (2003) "On The Determinants of First-Time Sovereign Bond Issues”, IMF Working Paper 03/184.

Gugiatti M. and A. Richards (2003), "Do Collective Action Clauses Influence Bond Yields? New Evidence from Emerging Markets", Reserve Bank of Australia, Research Discussion Paper 2003-02, March.

Jenks L. H. (1927), The Migration of British Capital to 1875, London: Thomas Nelson.

Kaminsky G. L. (1998), “Currency and Banking Crises: A Composite Leading Indicator”, Unpublished manuscript (Washington: Board of Governors of the Federal Reserve System).

Kaminsky G. L. and C. Reinhart (1999), "The Twin Crises: The Causes of Banking and Balance of Payments Problems", American Economic Review, Vol. 89.

Kaminsky G. L. and C. Reinhart (2000), "On crises, contagion and confusion”, Journal of International Economics, June Vol.51 (1). 
Kaminsky G. L., C. Reinhart and C. A. Vegh (2003), “The Unholy Trinity of Financial Contagion", NBER Working Paper No.10061.

Kendall M and A. Stuart (1979), The Advanced theory of statistics, Volume 2, Griffin, London, $4^{\text {th }}$ edition.

Klovland J. T. (1994), "Pitfalls in the estimation of the yield on British Consols, 18501914”, Journal of Economic History, Vol.54, No.1.

Kuczynski R. (1932), Bankers' profits from German loans, Brookings Institution, Washington.

La Semaine financière (various years), Paris.

Landes D. (1958), Bankers and Pashas, International Finance and Economic Imperialism in Egypt, London: Heinemann.

Lewis C. (1938), America's Stake in International Investments, Brookings Institution, Washington.

Lindert P. H. and P. J. Morton (1989), "How Sovereign Debt Has Worked”, in J.D. Sachs, ed., Developing Country Debt and the World Economy, Chicago, Illinois: University of Chicago Press.

Lysis (1908), Contre l'Oligarchie financière en France, Paris: Bureaux de La Revue.

Mauro P., N. Sussman and Y. Yafeh (2002), "Emerging Market Spreads: Then Versus Now", Quarterly Journal of Economics, Vol. 117(2).

Mauro P., N. Sussman and Y. Yafeh (2006), Emerging markets and financial globalization: sovereign bond spreads in 1870-1913 and today, Oxford: Oxford University Press.

Mintz I. (1951), Deterioration in the Quality of Foreign Bonds Issued in the United States 1920-30, NBER, Cambridge.

Montiel P. (2003), Macroeconomics in Emerging Markets, Cambridge: Cambridge University Press.

Moody's Investors Service (various years), Moody's Foreign and American Government Securities.

Neal L. and M. Weidenmier (2002), "Crises in the Global Economy from Tulips to Today: Contagion and Consequences", NBER Working Paper No.9147.

Nieto-Parra S. (2008), “Who Saw Sovereign Debt Crises Coming?”, OECD Development Centre, Working Paper No.274.

Poor's (various years), Poor's Volumes. 
Porzecanski A. (2005), "From Rogue Creditors to Rogue Debtors: Implications of Argentina's Default," International Finance 0510010, EconWPA.

Reinhart C. and K. Rogoff (2004), "Serial Default and the 'Paradox' of Rich to Poor Capital Flows", NBER Working Paper No.10296.

Reinhart C. and K. Rogoff (2009), "The Aftermath of Financial Crises" NBER Working Paper No.14656.

Reisen H. and J. Von Maltzan (1999), "Boom and Bust and Sovereign Ratings", OECD Development Centre, Working Paper No.148.

Roberts R. (1992), Schroders: Merchants And Bankers, London: Palgrave Macmillan.

Sturzenegger F. and J. Zettelmeyer (2005), "Haircuts: Estimating Investor Losses in Sovereign Debt Restructurings, 1998-2005”, IMF Working Paper No. 05/137.

Suzuki T. (1994), Japanese Government Loan Issues on the London Capital Market, 18701913. London: Athlone Press.

The Economist (various years), Investors' Monthly Manual, London.

The Times (various years), London.

Tomz M. (2007), Reputation and International Cooperation: Sovereign Debt across Three Centuries, Princeton: Princeton University Press.

U.S. Senate (1932), "Sale of Foreign Bonds or Securities in the United States", Hearings Before the Committee on Finance, Washington, D.C.

Van Rijckeghem C. and B. Weder (2003), "Spillovers through banking centers: A panel data analysis", Journal of International Money and Finance, Vol. 22 (4), pp. 483-509.

Vaslin J-M. (1999), Les rentes françaises au XIXe siècle - Le marché des fonds d'État était-il efficient?, Unpublished dissertation, Université d'Orléans.

Winkler M. (1933), Foreign Bonds - An Autopsy, New York: Roland Swain Company.

Zervos S. (2004), “The Transactions Costs of Primary Market Issuance: The Case of Brazil, Chile, and Mexico", World Bank Policy Research Working Paper Series.

Ziegler P. (1988), The Sixth Great Power. Barings, 1762-1929, London: Collins. 
Table 1. Characteristics of primary markets

\begin{tabular}{|c|c|c|c|c|}
\hline Period & $\begin{array}{l}\text { Number of } \\
\text { Underwriters }\end{array}$ & H-H Index & $\begin{array}{l}\text { Market share } \\
\text { Top Three (\%) }\end{array}$ & Names of To Three \\
\hline $1818-1829$ & 12 & 1667 & 64.6 & $\begin{array}{l}\text { Rothschild } \\
\text { Thomas Wilson } \\
\text { B.A. Goldschmidt }\end{array}$ \\
\hline $1845-1876$ & 45 & 2315 & 55.2 & $\begin{array}{l}\text { Rothschild } \\
\text { Imperial Ottoman Bank } \\
\text { Bischoffsheim \& Goldschmidt }\end{array}$ \\
\hline $1877-1895$ & 34 & 1200 & 50.1 & $\begin{array}{l}\text { Rothschild } \\
\text { Barings } \\
\text { Hambros }\end{array}$ \\
\hline 1895-1913: London & 33 & 1269 & 51.1 & $\begin{array}{l}\text { Hong Kong Bank } \\
\text { Rothschild } \\
\text { Barings }\end{array}$ \\
\hline 1895-1914: Paris & 14 & 1746 & 65.0 & $\begin{array}{l}\text { Rothschild } \\
\text { BPPB } \\
\text { Banque Impériale Ottomane }\end{array}$ \\
\hline 1920-1930: New York & 20 & 2869 & 68.9 & $\begin{array}{l}\text { JP Morgan } \\
\text { National City } \\
\text { Blair } \\
\end{array}$ \\
\hline 1993-2007: New York & 29 & 1145 & 48.0 & $\begin{array}{l}\text { JP Morgan } \\
\text { Citi } \\
\text { Morgan Stanley }\end{array}$ \\
\hline 1993-2007: London & 26 & 876 & 38.6 & $\begin{array}{l}\text { JP Morgan } \\
\text { UBS } \\
\text { Deutsche Bank }\end{array}$ \\
\hline 1993-2007: All & 43 & 842 & 39.4 & $\begin{array}{l}\text { JP Morgan } \\
\text { Citi } \\
\text { Deutsche Bank }\end{array}$ \\
\hline
\end{tabular}

Sources: See Appendix 1. 
Table 2. The Evolution of Underwriting Fees in the Very Long Run

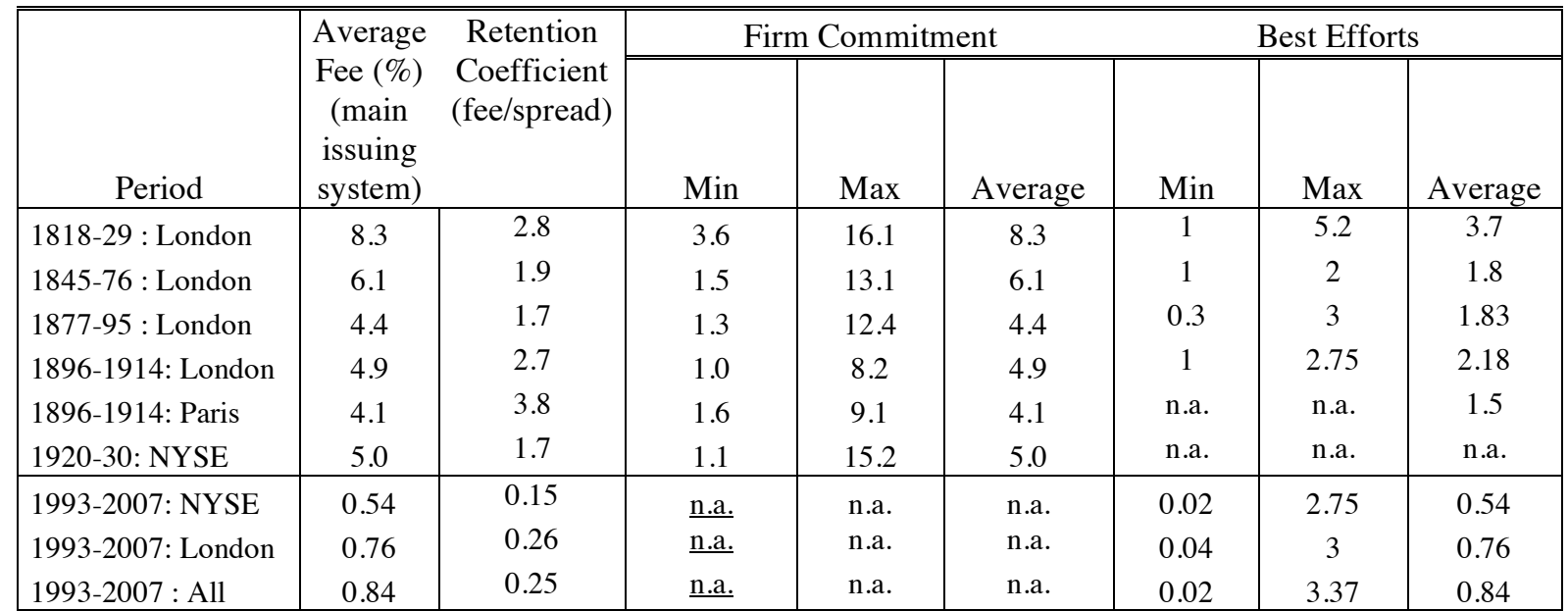

Sources: Authors' computations. Fees : Ziegler (1988), Select Committee (1875), Amaral (1984) Dawson (1990), Dritsas (1993), Anuario Estadistico (1927), Gille (1973), Flores (2004), Suzuki (1994), US Congress (1932). Archive: Rothschild Archives, ING Baring Archives, HSBC Archives, Crédit Lyonnais Archive, Guildhall Library. Spread at issue from sources described in data appendix. Benchmark risk free rates: London, NBER macrodatabase (before 1870) and Klovland (1994) after 1870; Paris: Vaslin (1999); New York interwar, Wall Street Journal. Modern period: Dealogic. 
Table 3. Fees and Spreads (Firm Taking)

\begin{tabular}{|c|c|c|c|}
\hline Period & R-squared & $\begin{array}{c}\text { Fee }=a+b * \text { spread } \\
(\mathrm{t} \text { statistics })\end{array}$ & $\begin{array}{l}\mathrm{H}_{0} \text { : Significance } \\
\text { of spread (at } 5 \% \text { ) }\end{array}$ \\
\hline 1818-29: London & n.a. & n.a. & n.a. \\
\hline 1845-76 : London & 0.56 & $\begin{array}{c}\text { Fee }=3.421+0.65^{*} \text { spread } \\
(3.17) \quad(2.75)\end{array}$ & Accept \\
\hline 1877-95 : London & 0.43 & 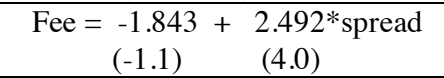 & Accept \\
\hline 1896-1913: London & 0.41 & Fee $=\begin{array}{l}1.9535 \\
(3.1)\end{array}$ & Accept \\
\hline 1896-1913: Paris & 0.65 & $\begin{array}{c}\text { Fee }=1.658+1.513 * \text { spread } \\
(8.53) \quad(5.85)\end{array}$ & Accept \\
\hline 1920-30: NYSE & 0.32 & $\begin{array}{c}\text { Fee }=0.62475+1.497 * \text { spread } \\
(1.00) \quad(7.24)\end{array}$ & Accept \\
\hline 1993-2007: NYSE & 0.0002 & $\begin{array}{c}\text { Fee }=\begin{array}{l}0.55642+0.004 * \text { spread } \\
(10.56)\end{array}(0.27)\end{array}$ & Reject \\
\hline 1993-2007: London & 0.027 & $\begin{array}{c}\text { Fee }=0.59129+0.052 * \text { spread } \\
(7.5) \quad(2.2)\end{array}$ & Accept \\
\hline 1993-2007 : All & 0.003 & $\begin{array}{c}\text { Fee }=0.8014+0.017 * \text { spread } \\
(12.6) \quad(1.29)\end{array}$ & Reject \\
\hline
\end{tabular}

Sources: Same as in Table 2.

Note: Sovereign bond spreads (spread) and fees are in percent. 
Table 4. Clusters of contagion

\begin{tabular}{|c|c|c|c|c|c|c|c|c|}
\hline & \multicolumn{6}{|c|}{$\begin{array}{c}\text { PAST } \\
14 \text { countries, 1822:3-1829:12 }\end{array}$} & \multirow{2}{*}{\multicolumn{2}{|c|}{$\begin{array}{c}\text { PRESENT } \\
\text { 1994:11-2004:2 } \\
\text { Total \& JP Morgan }\end{array}$}} \\
\hline & \multicolumn{2}{|c|}{ Total } & \multicolumn{2}{|c|}{ Non-Rothschild } & \multicolumn{2}{|c|}{ Rothschild } & & \\
\hline & 200 b.pts & $20 \%$ & 200 b.pts & $20 \%$ & 200 b.pts & $20 \%$ & 200 b.pts & $20 \%$ \\
\hline $\begin{array}{l}\text { Sharp Changes } \\
\% \text { of Obs. }\end{array}$ & 5.83 & 4.54 & 10.5 & 7.6 & 0 & 2.5 & 13.2 & 12.9 \\
\hline $\begin{array}{l}\text { \% Months without } \\
\text { Sharp Changes }\end{array}$ & 37.2 & 51.1 & 37.2 & 45.7 & 100 & 90.4 & 43.2 & 44.1 \\
\hline $\begin{array}{l}\text { Sharp Changes in } \\
\text { one Country }\end{array}$ & 20.2 & 26.6 & 20.2 & 25.5 & 0 & 8.5 & 30.6 & 34.2 \\
\hline $\begin{array}{l}\text { Sharp Changes in } \\
\text { Two Countries }\end{array}$ & 16.0 & 11.7 & 16.0 & 11.7 & 0 & 0 & 15.3 & 7.2 \\
\hline $\begin{array}{l}\text { Sharp Changes in } \\
\text { Three or More }\end{array}$ & 26.6 & 10.6 & 26.6 & 8.5 & 0 & 1.1 & 10.8 & 14.4 \\
\hline $\begin{array}{l}\text { Sharp Changes in } \\
\text { Two or More }\end{array}$ & 42.6 & 22.3 & 32.6 & 20.2 & 0 & 1.1 & 26.1 & 21.6 \\
\hline Contagion Ratio $*$ & 67.8 & 45.6 & 67.8 & 44.2 & 0 & 11.1 & 46.0 & 38.7 \\
\hline
\end{tabular}

Sources: Past: Authors' computations from Wetenhall (see Flandreau and Flores (2009) for details). Present: Mauro et al. (2006): p. 115. The 14 countries for the past are Argentina (Buenos Aires), Austria, Brazil, Chile, Colombia, Greek, Guatemala, Mexico, Naples, Peru, Portugal, Prussia, Russia, Spanish. The 8 countries for the Present are: Argentina, Brazil, Bulgaria, Mexico, Nigeria, Philippines, Poland, Venezuela. Because of missing observations, we may slightly under estimate the extent to which there were sharp changes.

* The Contagion Ratio is the proportion of sharp changes in at least two countries to sharp changes in at least one country. 
Table 5. The characteristics of emerging market debt

\begin{tabular}{|c|c|c|c|c|c|c|c|}
\hline Period & $\begin{array}{l}\mathrm{Nb} \text { of } \\
\text { bonds }\end{array}$ & $\begin{array}{l}\mathrm{Nb} \text { of } \\
\text { Countries }\end{array}$ & $\begin{array}{l}\text { Amount } \\
\text { (min, max, } \\
\text { average) }\end{array}$ & $\begin{array}{l}\text { In } 2008 \$ \\
\text { (min, } \\
\text { max, } \\
\text { average) }\end{array}$ & $\begin{array}{l}\text { Maturity } \\
\text { (min, max, } \\
\text { average) }\end{array}$ & $\begin{array}{l}\text { Yield Prem. at } \\
\text { launch } \\
\text { (min, max, } \\
\text { average) bps. }\end{array}$ & $\begin{array}{l}\text { Rating at } \\
\text { launch } \\
\text { (max, min, } \\
\text { average) }\end{array}$ \\
\hline $\begin{array}{l}\text { 1818-1829: } \\
\text { London }\end{array}$ & 23 & 14 & $\begin{array}{l}0.6 £ \mathrm{M} \\
6.4 £ \mathrm{M} \\
2.5 £ \mathrm{M}\end{array}$ & $\begin{array}{l}65.7 \$ M \\
701 \$ M \\
273.8 \$ M\end{array}$ & $\begin{array}{l}20 \text { years } \\
60 \text { years } \\
31 \text { years }\end{array}$ & $\begin{array}{l}84 \\
597 \\
357\end{array}$ & N.A. \\
\hline $\begin{array}{l}\text { 1845-1876: } \\
\text { London }\end{array}$ & 148 & 39 & $\begin{array}{l}0.1 £ \mathrm{M} \\
165 £ \mathrm{M} \\
7.5 £ \mathrm{M}\end{array}$ & $\begin{array}{l}9.9 \$ M \\
16331 \$ M \\
742 \$ M\end{array}$ & $\begin{array}{l}8 \text { years } \\
98 \text { years } \\
33 \text { years }\end{array}$ & $\begin{array}{l}66 \\
933 \\
397 \\
\end{array}$ & N.A. \\
\hline $\begin{array}{l}\text { 1877-1895: } \\
\text { London }\end{array}$ & 106 & 29 & $\begin{array}{l}0.04 £ \mathrm{M} \\
140 £ \mathrm{M} \\
6.3 £ \mathrm{M}\end{array}$ & $\begin{array}{l}4.5 \$ \mathrm{M} \\
15759 \$ \mathrm{M} \\
709 \$ \mathrm{M}\end{array}$ & $\begin{array}{l}5 \text { years } \\
99 \text { years } \\
47.6 \text { years }\end{array}$ & $\begin{array}{l}28 \\
685 \\
275\end{array}$ & N.A. \\
\hline $\begin{array}{l}\text { 1895-1913: } \\
\text { London }\end{array}$ & 100 & 30 & $\begin{array}{l}0.07 £ \mathrm{M} \\
38.4 £ \mathrm{M} \\
3.8 £ \mathrm{M}\end{array}$ & $\begin{array}{l}7.75 \$ M \\
4250 \$ M \\
420.6 \$ M\end{array}$ & $\begin{array}{l}5 \text { years } \\
98 \text { years } \\
43.3 \text { years }\end{array}$ & $\begin{array}{l}17 \\
500 \\
215\end{array}$ & N.A. \\
\hline $\begin{array}{l}\text { 1880-1913: } \\
\text { Paris }\end{array}$ & 121 & 29 & $\begin{array}{l}10 \text { FFM } \\
1362 \text { FFM } \\
177.6 \text { FFM }\end{array}$ & $\begin{array}{l}48.4 \$ M \\
6725 \$ M \\
876 \$ M\end{array}$ & $\begin{array}{l}5 \text { years } \\
98 \text { years } \\
50.4 \text { years }\end{array}$ & $\begin{array}{l}-49.6 \\
368 \\
125\end{array}$ & N.A. \\
\hline $\begin{array}{l}\text { 1920-1930: } \\
\text { New York }\end{array}$ & 124 & 36 & $\begin{array}{l}0.148 \$ M \\
125 \$ M \\
26.29 \$ M\end{array}$ & $\begin{array}{l}1.82 \$ M \\
1535 \$ M \\
323 \$ M \\
\end{array}$ & $\begin{array}{l}2 \text { years } \\
50 \text { years } \\
26.7 \text { years }\end{array}$ & $\begin{array}{l}42 \\
455 \\
291 \\
\end{array}$ & $\begin{array}{l}\text { Aaa } \\
\text { B } \\
\text { A }\end{array}$ \\
\hline $\begin{array}{l}\text { 1993-2007: } \\
\text { New York }\end{array}$ & 404 & 33 & $\begin{array}{l}3 \$ \mathrm{M} \\
3951 \$ \mathrm{M} \\
698 \$ \mathrm{M} \\
\end{array}$ & $\begin{array}{l}3.75 \$ M \\
4940 \$ M \\
873 \$ M \\
\end{array}$ & $\begin{array}{l}1.5 \text { years } \\
100 \text { years } \\
12.6 \text { years }\end{array}$ & $\begin{array}{l}53 \\
824 \\
364 \\
\end{array}$ & $\begin{array}{l}\mathrm{A}+ \\
\mathrm{B}- \\
\mathrm{BB}\end{array}$ \\
\hline $\begin{array}{l}\text { 1993-2007: } \\
\text { London }\end{array}$ & 236 & 34 & $\begin{array}{l}19.9 \$ M \\
3910 \$ M \\
480 \$ M\end{array}$ & $\begin{array}{l}24.9 \$ M \\
4889 \$ M \\
600 \$ M\end{array}$ & $\begin{array}{l}1.5 \text { years } \\
35 \text { years } \\
7 \text { years }\end{array}$ & $\begin{array}{l}21.6 \\
825 \\
288\end{array}$ & $\begin{array}{l}\mathrm{AA}- \\
\mathrm{CCC}+ \\
\mathrm{BB}+\end{array}$ \\
\hline $\begin{array}{l}\text { 1993-2007: } \\
\text { All }\end{array}$ & 876 & 50 & $\begin{array}{l}3 \mathrm{\$ M} \\
3951 \$ \mathrm{M} \\
558 \$ \mathrm{M}\end{array}$ & $\begin{array}{l}3.75 \$ M \\
4940 \$ M \\
698 \$ M\end{array}$ & $\begin{array}{l}1.5 \text { years } \\
100 \text { years } \\
9.9 \text { years }\end{array}$ & $\begin{array}{l}11.6 \\
825 \\
333\end{array}$ & $\begin{array}{l}\mathrm{AA}- \\
\mathrm{CCC}+ \\
\mathrm{BB}+\end{array}$ \\
\hline
\end{tabular}

Sources: Authors' database, see Appendix 1. 
Figure 1. Cramèr's V: Are Defaults Randomly Distributed Across Underwriters?

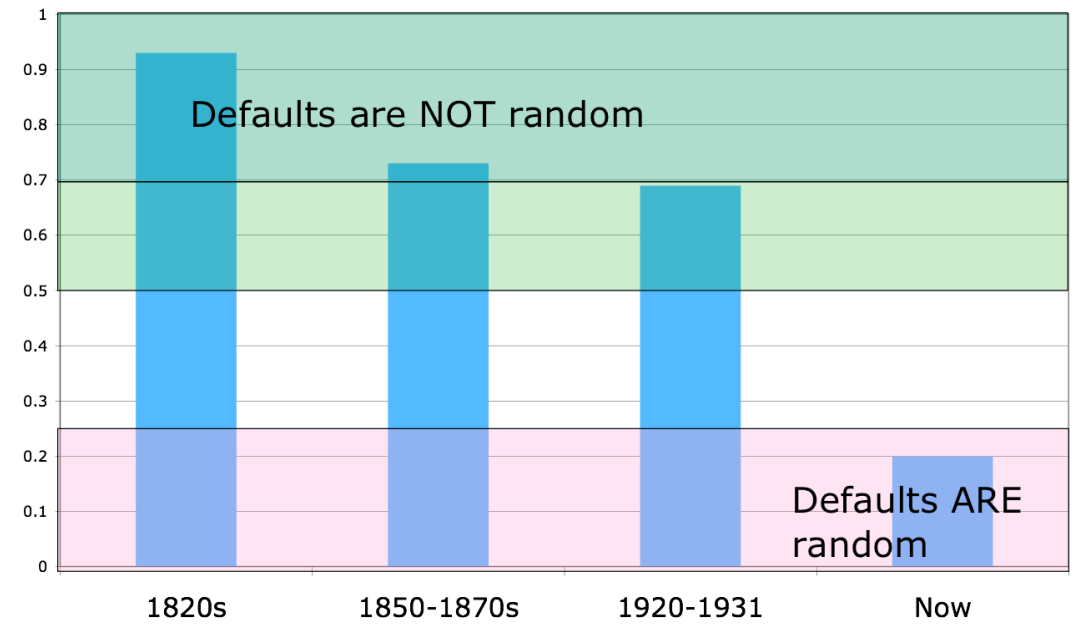

Source: Authors' computations 
Figure 2a: Ranking of top 10 underwriters by market share (percentage), 1818-1829

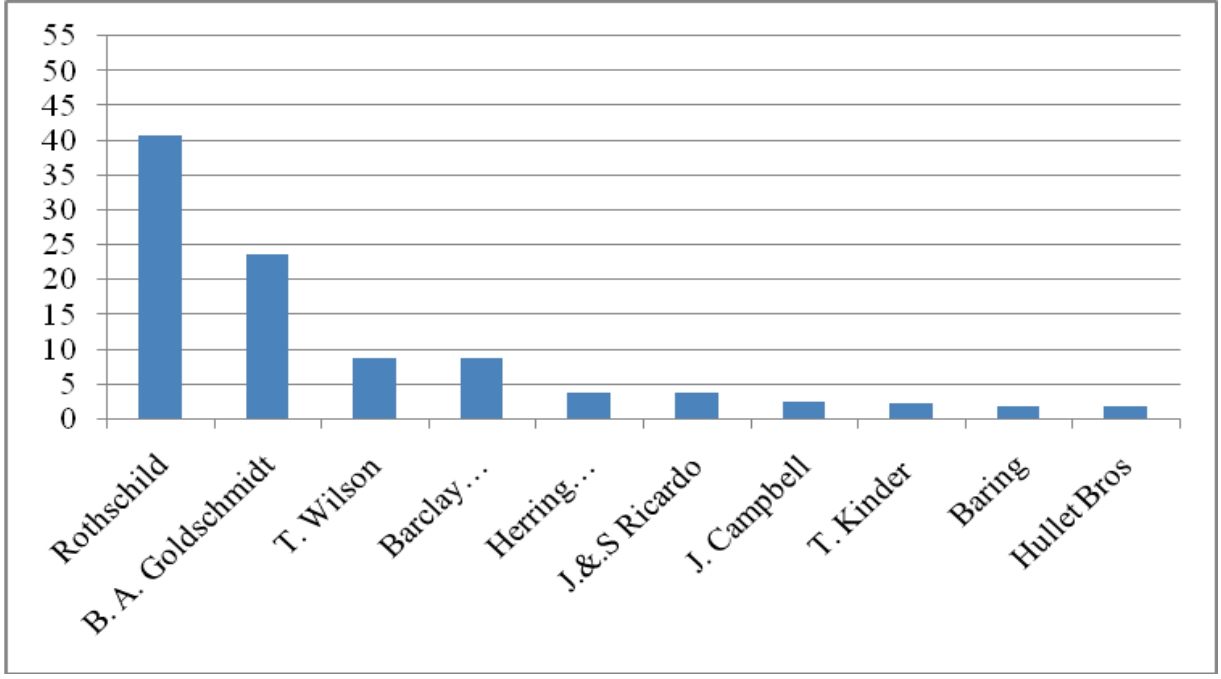

Figure 2b: Ranking of top 10 underwriters by market share (percentage), 1845-1876

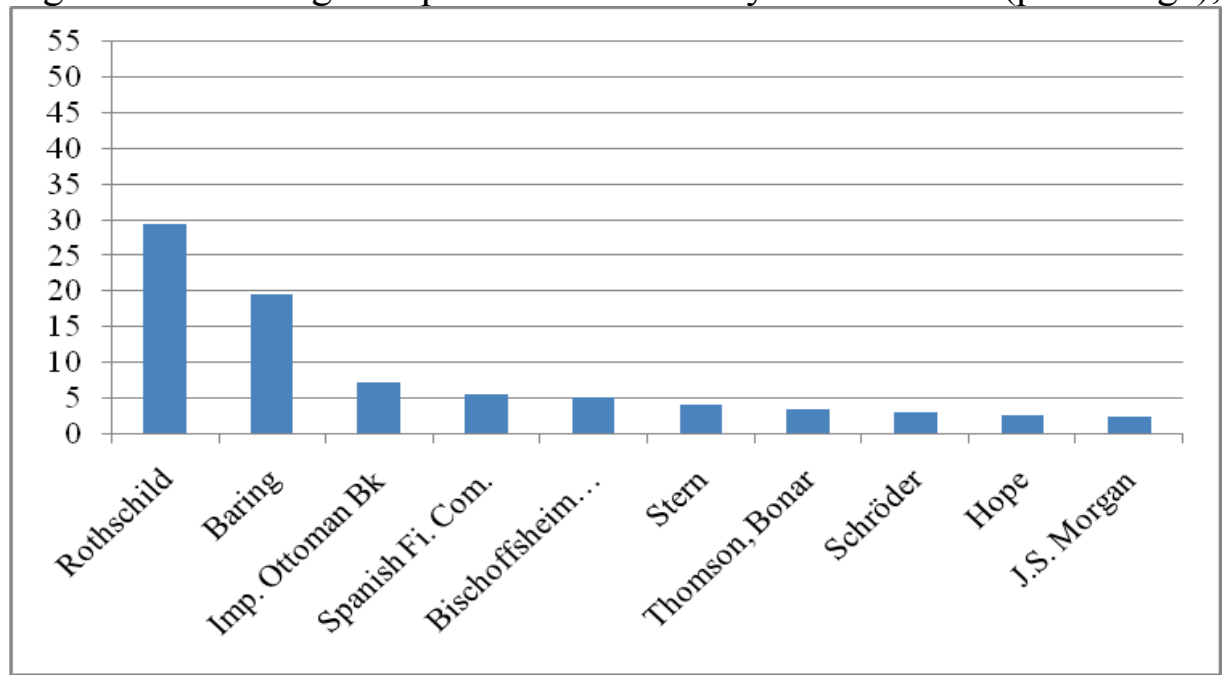

Figure 2c: Ranking of top 10 underwriters by market share (percentage), 1877-1895

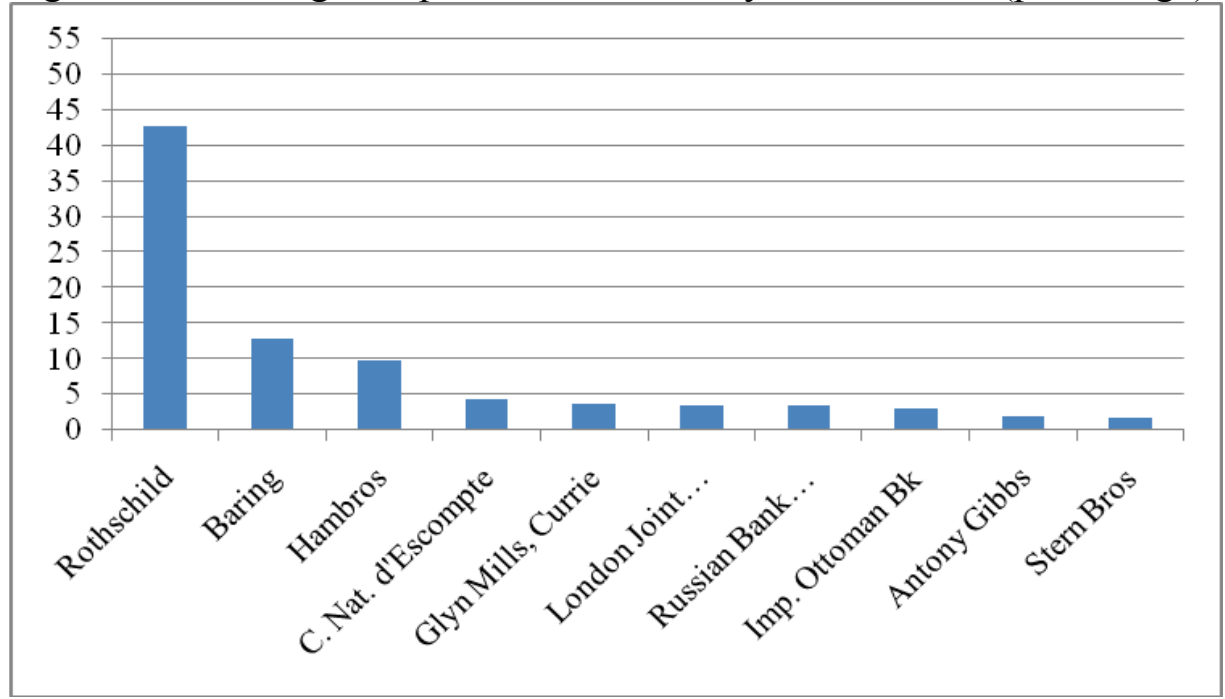


Figure 2d: Ranking of top 10 underwriters by market share (percentage), 1920-1930

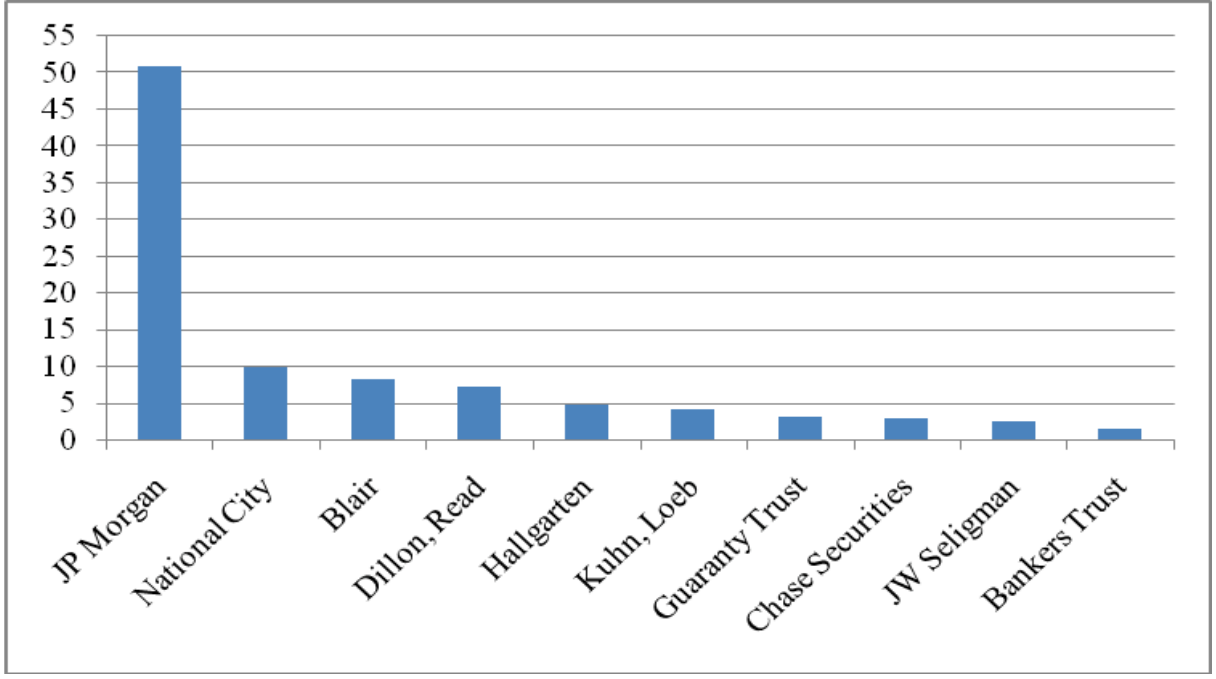

Figure 2e: Ranking of top 10 underwriters by market share (percentage), NY 1993-2007

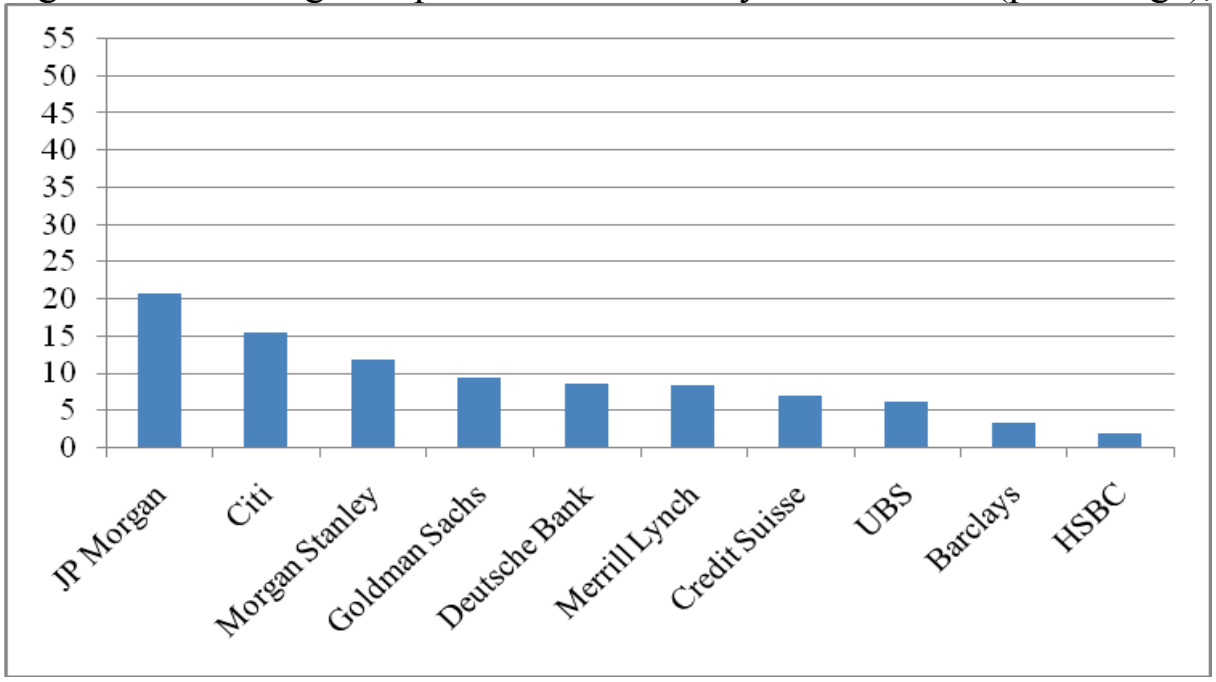

Sources: Authors' database, see Appendix 1. 
Figure 3a. Spreads at issue: Market leader vs. the rest (NY, Interwar).

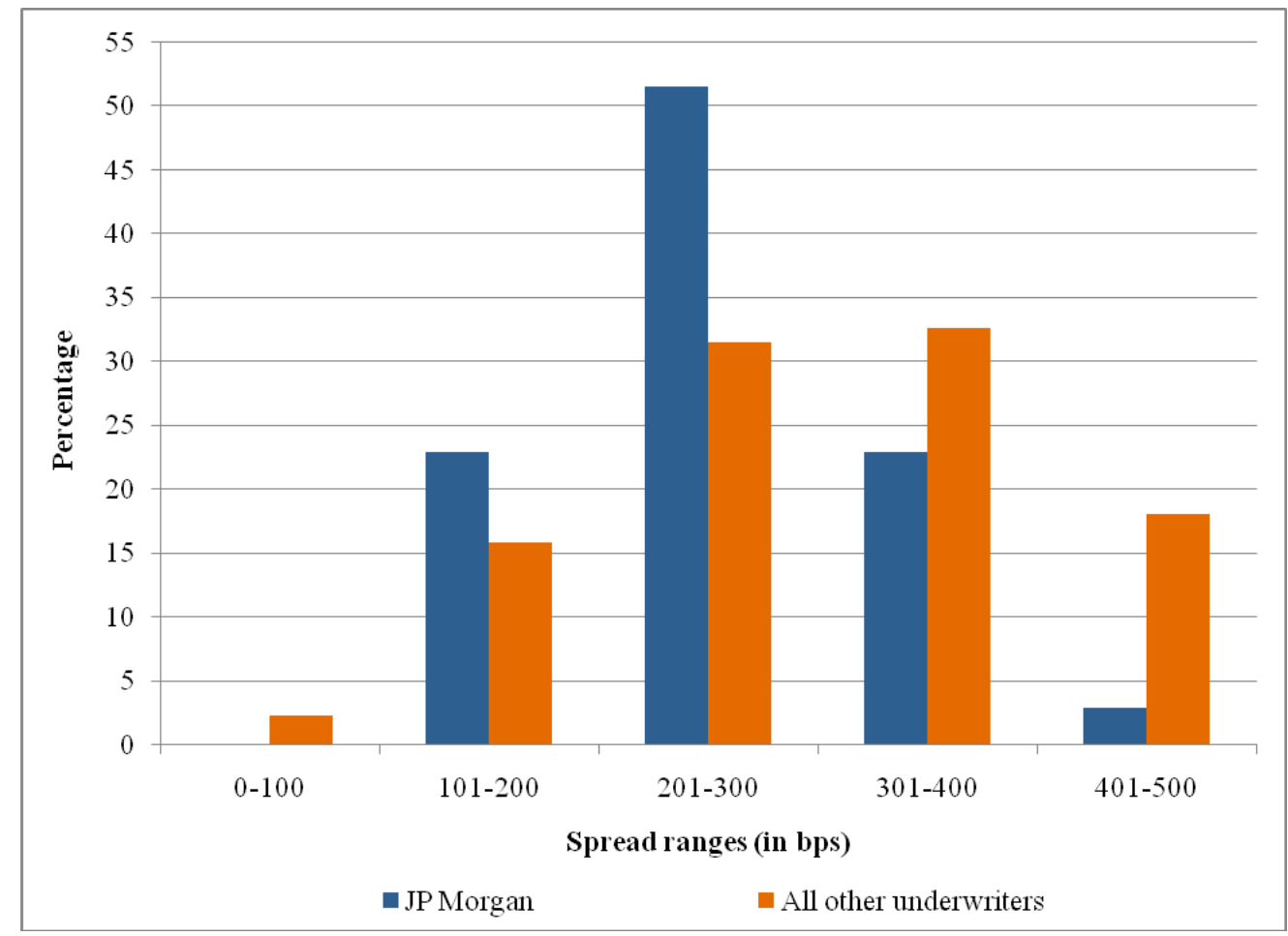

Figure 3b. Spreads at issue: Market leader vs. the rest (NY, modern era).

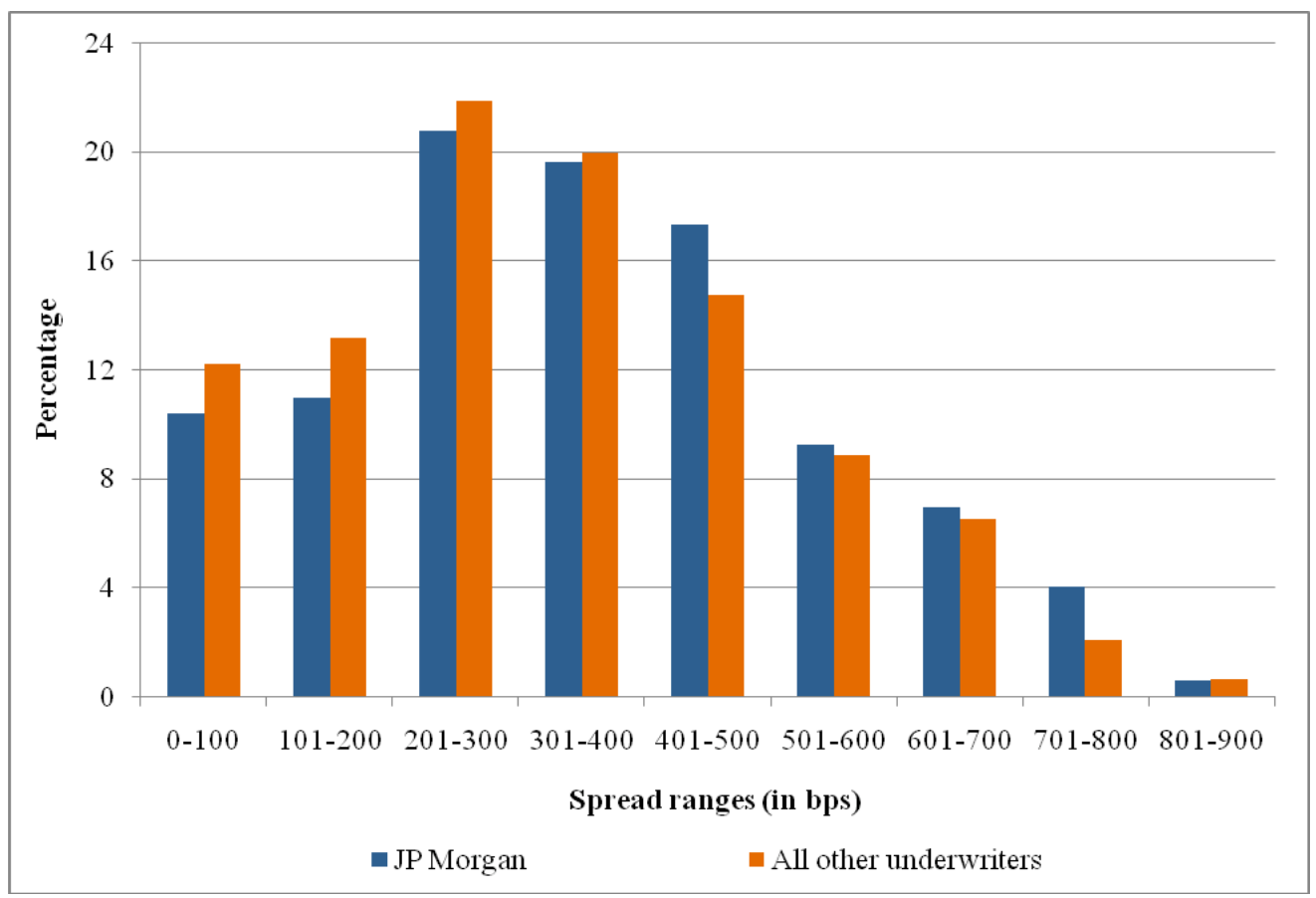

Sources: Authors' database, see Appendix 1. 
Figure 4. Risk Taking: Leaders and Followers

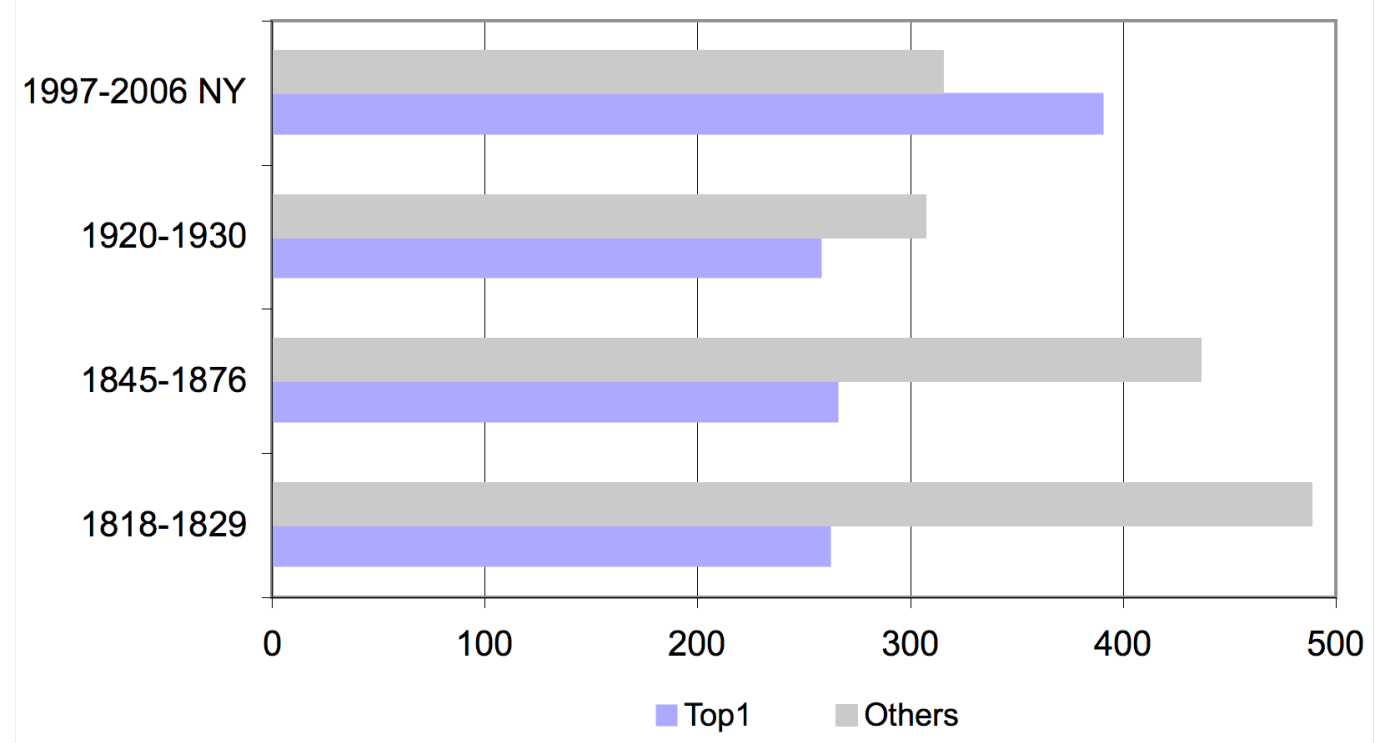

Sources: Authors' computations from own database, see Appendix 1. 
Figure 5. Lorenz curves: 3 debt crises (1820s, 1870s, 1930s) vs. today.

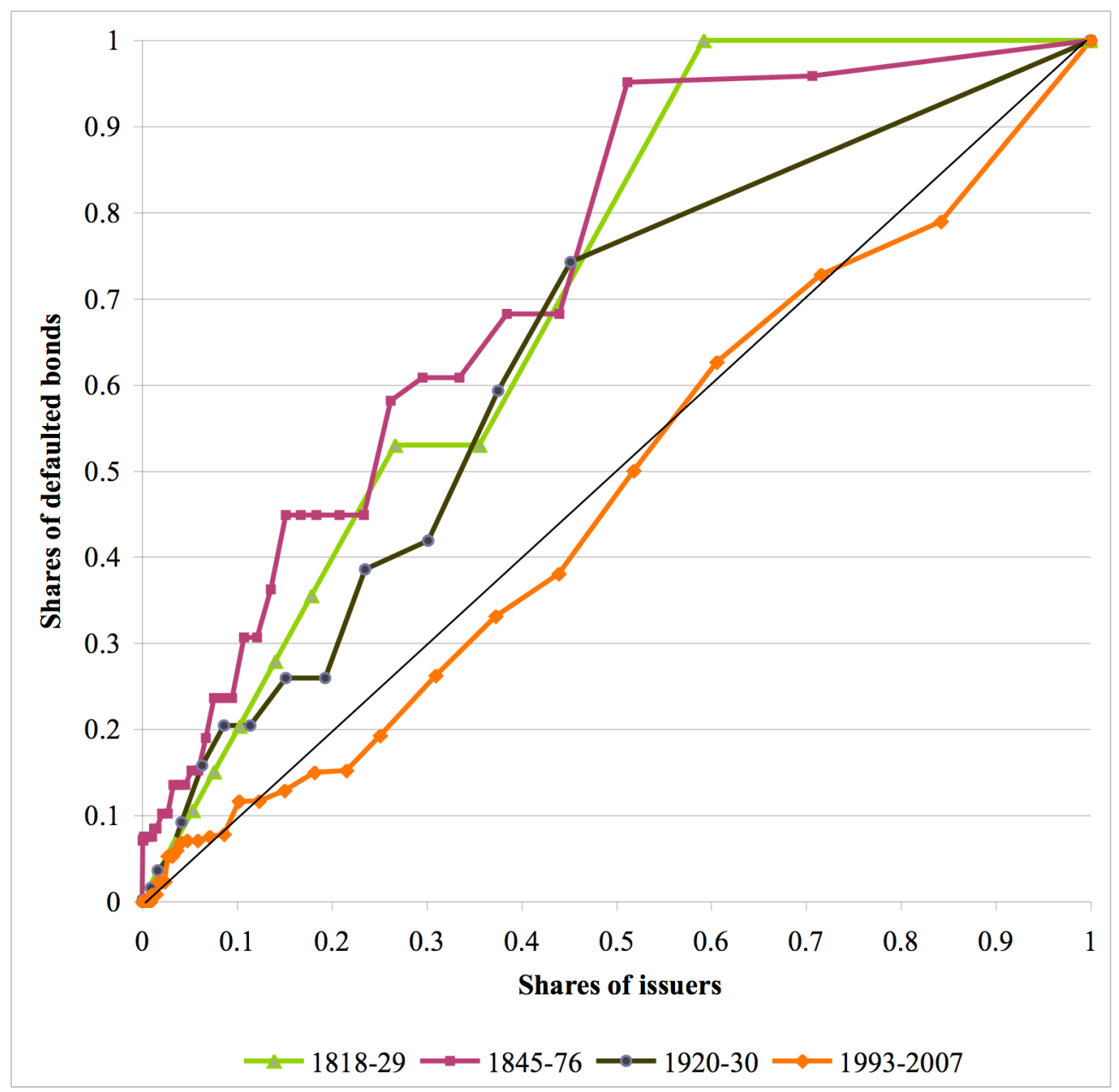

Sources: Authors' database, see Appendix 1. 
Figure 6a. Turnover (\%) and spreads (bps): Now

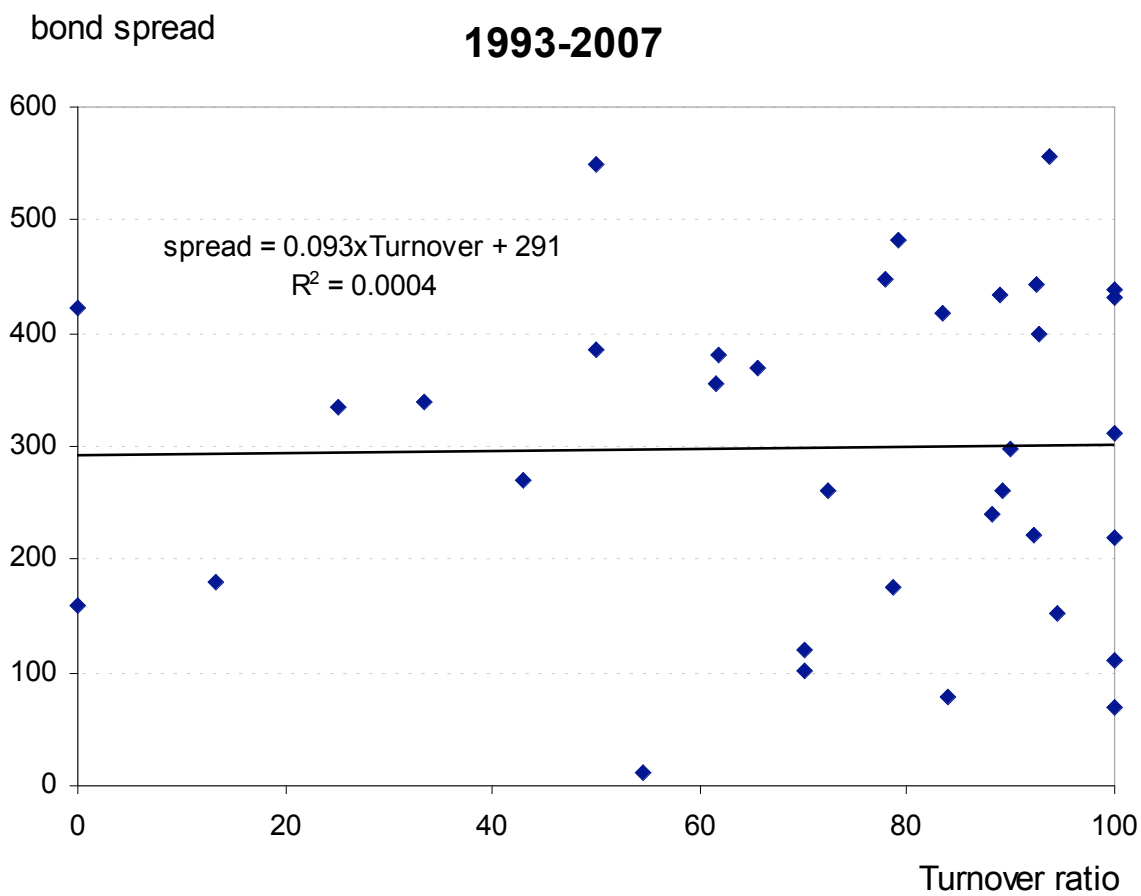

Figure $6 \mathrm{~b}$. Turnover and spreads: Late $19^{\text {th }}$ century

bond spread

$1870-1913$

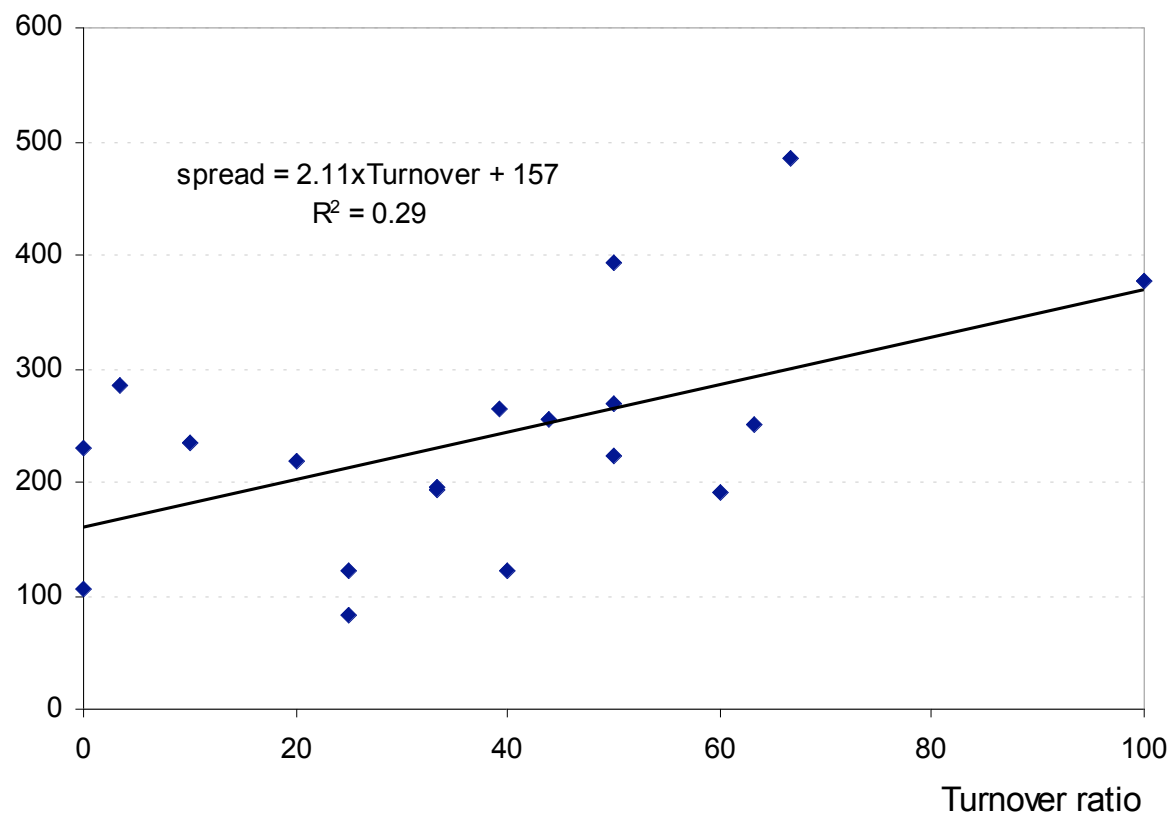

Sources: Authors' database, see Appendix 1. 
Figure 7. Percent. Investment Grade and Speculative Grade Securities (Interwar and now)

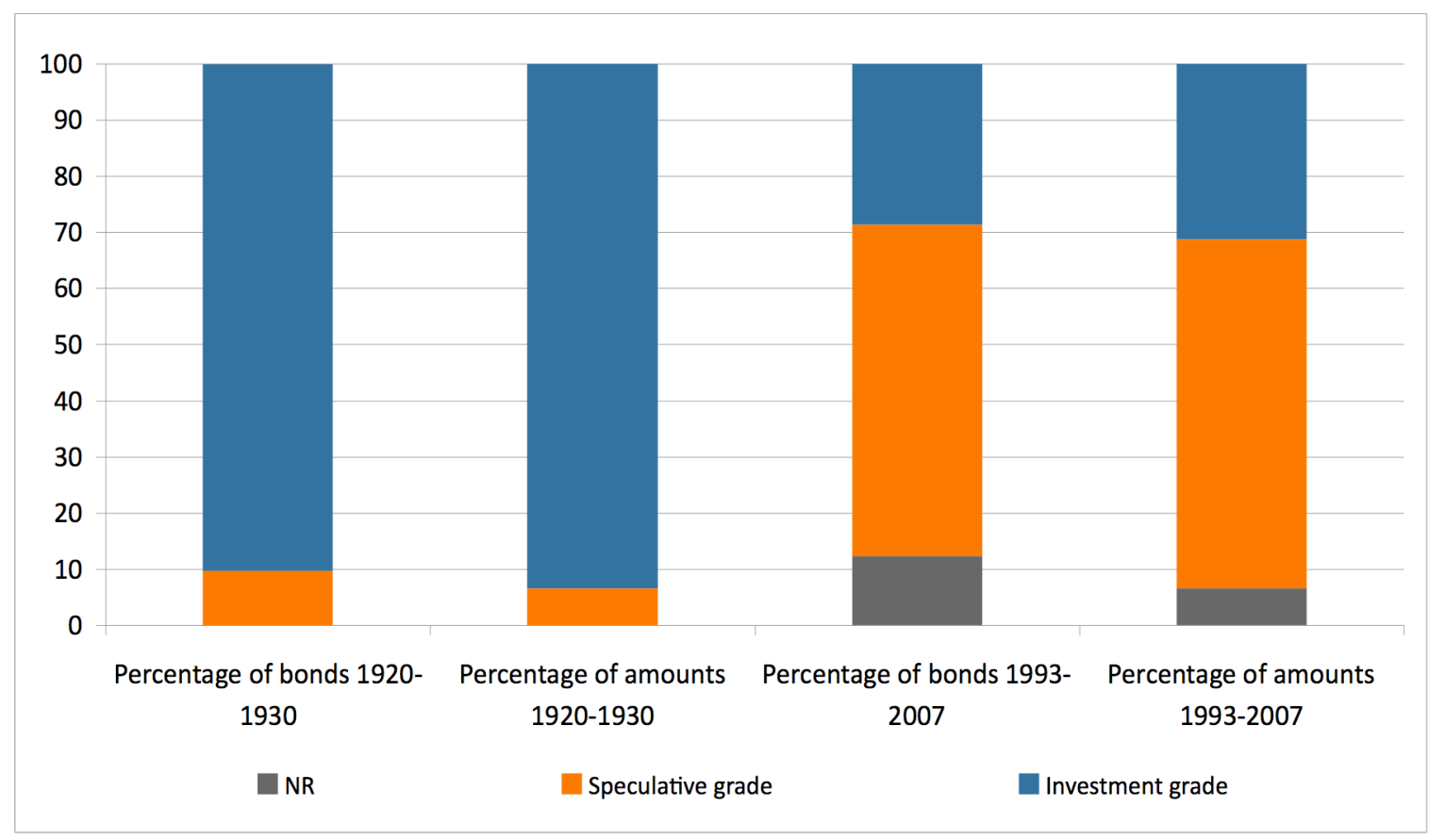

Sources: Authors' database, see Appendix 1 and Appendix 3. 
Appendix 1. Data

\section{Historical sample}

Data on the characteristics of financial instruments were collected using traditional London sources such as Fortune's Epitome, the Reports of Corporation of Foreign Bondholders, Burdett's Stock Market Official Intelligence, London Stock Exchange Official Intelligence and the financial press (The Economist and its supplement, the Investors' Monthly Manual) and The Times. For Paris, we relied on the Annuaire Officiel des Agents de Change (18821914) ${ }^{47}$ For New York, we have relied on the Manuals by Moody's, Fitch and Poor's as well as on the US Senate Committee on Finance Hearings on the Sale of Foreign Bonds published 1932. Data on defaults are obtained from these sources.

\section{Modern period}

The now period (1993-2007) is covered using DCM Analytics, the fixed income product of Dealogic (global coverage of the debt capital markets), an investors and financial intermediaries service. It is described in Nieto-Parra (2009). For defaults, we combined a dataset for sovereign default on foreign currency debt provided by Moody's (2008) and a useful database from Sturzenegger and Zettelmeyer (2005), which we matched against the Dealogic population of issues. ${ }^{48}$

Fees

Apart from occasional mentions in the contemporary press or in secondary sources indicated in sources for tables, material on fees does not exist for the early periods. It was entirely constructed from archives. The patience of archivists from Rothschild, ING-Baring (Baring Brothers), HSBC (Hong Kong and Shanghai Banking Corporation), and the Guildhall library (Hambro, and London Stock Exchange Archive), BNP-Paribas (Banque de Paris et des Pays-Bas), Crédit Agricole (Crédit Lyonnais), the Centre d'Archives du Monde du Travail (Rothschild frères, Banque Impériale Ottomane), is gratefully acknowledged for they allowed us to open literally hundreds of boxes in search for original contracts.

Regarding the interwar period, fees have been previously published by Lewis (1938), Kuczinski (1932). Both have worked with, and somewhat interpreted, the evidence in the four

\footnotetext{
47 . It covers securities sold in the official market where most government securities were transacted.

48 . Database available at http://profesores.utdt.edu/ fsturzen/Publications.htm. To make sure that we were not losing out any of the many bonds defaulted upon by Argentina in 2001 (Porzecanski, 2005), we also considered (www.mecon.gov.ar/finanzas/download/anexo_comunicado_prensa.pdf) a database provided by the Ministry of Finance of Argentina as well as material provided by the Argentine Bond Restructuring Agency (available at www.hypovereinsbank.de/media/pdf/Wertpapierliste.pdf).
} 
volumes US Senate Committee on Finance Hearings on the Sale of Foreign Bonds. We went back to this source. Finally, fees for modern times are available in Dealogic's Bondware.

Bond prices.

Bond price series used in section V are the same as in Flandreau and Flores (2009). They provide a detailed description of the material. 
Appendix 2. Spreads and fees

In this appendix, we discuss factors that determine the fee collected by an underwriter in the event of full underwriting. Our goal is to demonstrate that fees are an increasing function of risk and thus, since spreads measure risk, of spreads. For this purpose, we consider a government facing an underwriting industry that is made of competitive, risk neutral, firms. We call $p$ the "shadow" price that would be expected to prevail on the issue date if the issue was taking place directly on the market. The shadow price may be thought of as an indicator of liquidity. An adverse liquidity shock on the day of the issue would force the government to sell the bond at a discount, while a favorable one would yield a premium. Calling $u$ a random shock with a uniform distribution $[-a, a]$ such that $E(u)=0$ (with $0 \leq a \leq 1$ ), we write without loss of generality:

$$
p=1+u,
$$

The problem at hand is to determine, given the issue price $p_{E}$, the price at which the underwriting syndicate purchases the bond from the government or $p_{A}=p_{A}\left(p_{E}, a\right)$. Suppose that at the date of the issue the shadow price is above the issue price. Then investors will want to subscribe the bond and the issue is entirely sold to the market. The bank having purchased the bond from the government at $p_{A}$ resells it to the public at $p_{E}$ and makes a gain of $p_{E}-p_{A}$ per share. If by contrast the shadow price is below the issue price, nobody will want to purchase the bond and the bank makes either a gain or a loss, depending on the sign of $p-p_{A}$. Because of the risk of losing money if the issue turns awry, the bank will only accept to buy the bond from the government at a price that is sufficiently low so that the gains in the favorable states of nature compensate the losses incurred in unfavorable ones. ${ }^{49}$

In this setting, two critical assumptions help determine $p_{A}$. First, risk neutrality ensures that a bank is happy with a compensation that is just equal to the average loss she expects to make in unfavorable states of nature. Second, the competitive structure of the industry ensures that she will not ask for a higher compensation than the one that offsets its expected losses (otherwise the government will turn to another bank).

\footnotetext{
${ }^{49}$. For simplicity, we consider that a shadow price exactly equal to the issue price means a success. In practice, transaction costs, as agents have to switch from identical assets to purchase the new one, imply that the issue will only succeed if the issue price is marginally below the shadow price so that investors are compensated for the expenses they face in reallocation their portfolio. Transaction costs are frequently mentioned as being the reason why there is today an "IPO" discount, i.e. that new bonds are on average sold marginally below the price at which similar assets are traded (ref?). This question being of second order compared to what we deal with here, we abstract from it.
} 
As implied from what we already stated, the bank will gain $p_{E}-p_{A}$ if $u \geq p_{E}-1$, and will gain/lose $p^{i}-p_{A}^{i}=1+u^{i}-p_{A}^{i}$ if $-a \leq u<p_{E}-1$. The expected gain $G$ from underwriting the bond issue is:

$$
G=\left(p_{E}^{i}-p_{A}^{i}\right) \cdot\left\{\frac{a^{i}-\left(p_{E}^{i}-1\right)}{2 a^{i}}\right\}+\frac{1}{2 a^{i}} \int_{-a^{i}}^{p_{E}^{i}-1}\left(1+u^{i}-p_{A}^{i}\right) d u^{i}
$$

The zero profit condition tying $p_{E}$ and $p_{A}$ together, given $a$, is thus:

$$
\left(p_{E}-p_{A}\right) \cdot\left(a-p_{E}+1\right)+\frac{1}{2} \cdot\left\{\left(p_{E}-1\right)^{2}-a^{2}\right\}+\left\{\left(1-p_{A}\right) \cdot\left(p_{E}-1+a\right)\right\}=0
$$

This equation determines $p_{A}$ as an implicit function of $p_{E}$. In a more general approach, it would be interesting to treat $p_{E}$ as endogenous as well and derive both prices as model solutions. However, since the basic property considered here obtains for any $p_{E}$ it is just as good to focus on the determination of $p_{A}$ only. For simplicity, therefore, and in line with the discussion above we assume that the underwriting syndicate marks the issue to market and sets the issue price at the expected shadow price on the day of the issue. Therefore:

$$
p_{E}^{i}=1
$$

Substituting this in the previous equation, we then get simply:

$$
p_{A}^{i}=1-\frac{a^{i}}{4}
$$

And the underwriting fee:

$$
p_{E}^{i}-p_{A}^{i}=\frac{a^{i}}{4}
$$

This shows that the larger the variance of the expected liquidity shock on the market for bond i (or identically the more volatile the price of bond i), the larger the "haircut" that a competitive risk neutral bank will require in order to underwrite the issue of that bond. If volatility is maximum $\left(a^{i}=1\right)$ banks only accept government bonds at $75 \%$ of their issue price the issue. By contrast, if there is no volatility $\left(a^{i}=0\right)$ banks take the bonds from the government at the very price at which they resell them to the public and the underwriting fee is zero. The important point here is that the fee charged for full underwriting must be an increasing function of the risk of the bond. 
Appendix 3. Keys for Granularity

\begin{tabular}{|c|c|}
\hline Moody's rating scale, 1920-30 & Moody's rating scale, 1993-2007 \\
\hline \multicolumn{2}{|c|}{ Investment Grade } \\
\hline Aaa & Aaa \\
\hline \multirow{3}{*}{$\mathrm{Aa}$} & Aa1 \\
\hline & Aa2 \\
\hline & Aa3 \\
\hline \multirow{3}{*}{ A } & A1 \\
\hline & $\mathrm{A} 2$ \\
\hline & A3 \\
\hline \multirow{3}{*}{ Baa } & Baa1 \\
\hline & Baa2 \\
\hline & Baa3 \\
\hline \multicolumn{2}{|c|}{ Speculative Grade } \\
\hline \multirow{3}{*}{$\mathrm{Ba}$} & $\mathrm{Ba} 1$ \\
\hline & $\mathrm{Ba} 2$ \\
\hline & $\mathrm{Ba} 3$ \\
\hline \multirow{3}{*}{ B } & B1 \\
\hline & $\mathrm{B} 2$ \\
\hline & B3 \\
\hline \multirow{3}{*}{ Caa } & Caa1 \\
\hline & $\mathrm{Caa} 2$ \\
\hline & $\mathrm{Caa} 3$ \\
\hline $\mathrm{Ca}$ & $\mathrm{Ca}$ \\
\hline $\mathrm{C}$ & $\mathrm{C}$ \\
\hline
\end{tabular}

Source: Authors, from Moody's Manuals. 